\title{
8
}

\section{Towards estimating agricultural production relations for China ${ }^{1}$}

\author{
Peter Albersen, Günther Fischer, Michiel Keyzer and Laixiang \\ Sun $^{2}$
}

Fast economic growth has stimulated China's demand for food and feed grains. While the country has an impressive record in raising its agricultural production, it is not entirely clear to what degree China can, or should, maintain food self-sufficiency, and whether eventual imports should consist of meat or feed grains. The answer to these questions is not only important for China. It has strong implications for world markets at large. In its World Food Prospects, the International Food Policy Research Institute (IFPRI) (Pinstrup-Andersen et al. 1999) anticipates that net meat exports to East Asia will be 28 -fold in 2020, primarily because the demand for meat in China is expected to double. The demand for maize as main feed grain will grow by 2.7 per cent per year.

Successful economic development, however, has itself created new room for choice and may render irrelevant any prediction that merely extrapolates past trends. Based on this recognition, the IIASA Land Use Change (LUC) Project has opted for an approach that seeks to identify alternative options for agricultural policy through a spatially explicit intertemporal model. ${ }^{3}$ This model accounts for the main biophysical restrictions in various parts of the country, in conjunction with the main socio-economic factors that drive land-use and land-cover change (Fischer et al. 1996).

This chapter documents the specification of the input-output relationships for crop production and reports the estimation results. These relationships describe, for each of some 2040 counties in China in the year 1990, the crop output combinations that can, under the prevailing environmental conditions (such as climate, terrain, soils) be produced from given combinations of chemical and organic fertilisers, labour and traction power, and irrigated and rainfed land. The relationships are estimated separately for the eight economic regions 


\section{Dilemmas of China's Growth in the Twenty-First Century}

distinguished in the LUC model. ${ }^{4}$ In addition to these input-output relations for crop production, the LUC model also contains components for livestock production, consumer demand, land conversion and water development. These will be presented in separate reports.

Several examples exist in the literature of agricultural production functions which were estimated for China. The major interest was to generally assess the level of the total factor productivity and its change, to estimate the marginal productivity and output elasticities of the main production factors and to evaluate the specific contribution of rural reform to agricultural growth. On the basis of pooled data at the provincial level, Lin (1992) assesses the contributions of decollectivisation, price adjustments and other reforms to China's agricultural growth in the reform period. The study estimates that decollectivisation accounted for about half of the output growth during 197884. Wiemer (1994) uses micro-panel data from households and production teams in a rural township to analyse the pattern and change of rural resource allocation before and after the reform. Both studies applied a Cobb-Douglas form to specify an agricultural production function with four conventional inputs: land, labour, capital and chemical fertiliser (or intermediate inputs). Additional variables needed for the specific assessment purposes were incorporated into the exponential term of the Cobb-Douglas form.

Two recent studies by Carter and Zhang (1998) and Lindert (1999) incorporate climate and biophysical information as well as the conventional inputs. Carter and Zhang estimate a Cobb-Douglas model for grain productivity for the five major grain-producing regions in China with aridity indices using data between 1980-90. Lindert estimates the agricultural and grain productivity for both North and South China with a mixed translog and CobbDouglas specification using soil chemistry indices from soil profiles and inputoutput data at the county level. In both studies fertiliser input was limited to chemical fertiliser, although the manure aspect is implicitly incorporated by Lindert in an organic matter index.

Our aim to include the crop input-output relationships within the wider LUC welfare optimum model imposes various requirements.

First, an adequate representation of environmental conditions relevant to agricultural land use patterns should be reflected in the LUC model. To ensure this, the biophysical potentials as computed from an agro-ecological assessment were included in the crop production function in a form that fits meaningfully within the economy-wide model. The potentials enter through the vector of land resources and a maximal yield that serves as an asymptote to actual yields. The building bricks for the potential output calculation are potential yields at county level for different land types (irrigated and rainfed) and for major seasonal crops (such as winter and summer crops corresponding to relevant Asian 


\section{Towards estimating agricultural production relations for China}

monsoon seasons in China). These county-level potential yields were compiled in the LUC Project's land productivity assessment component, based on the experiences gained in site experiments employing detailed crop process models (Rosenzweig et al. 1998) and applying a China-specific implementation of the enhanced Agro-Ecological Zones (AEZ) methodology (Fischer et al. 2000). The AEZ assessment is a well-developed environmental approach. It provides an explicit geographic dimension for establishing spatial inventories and databases of land resources and crop production potential. The method is comprehensive in terms of the coverage of factors affecting agricultural production, such as components of climate, soil and terrain. It takes into account basic conditions in supply of water, energy, nutrients and physical support to plants. The AEZ method uses available information to the maximum. Moreover, it is also directly applicable to assessing changes in production potential in response to scenarios of climate change.

Second, the functions must satisfy global slope and curvature conditions (convexity for the output index and concavity for the input response function). These were imposed through respective restrictions on the relevant function parameters.

Third, the estimations must accommodate the limitations of the available information. For instance, no data was available on crop-specific inputs, such as fertiliser applied to wheat. This lack of information is not specific to China but is a fairly common situation in agricultural sector modelling, making it impossible to identify the parameters of separate crop-specific production functions. The usual approach is to represent the technology via a transformation function with multiple outputs jointly originating from a single production process with multiple inputs. Under the assumption of revenue maximisation this approach enables us to identify derived net output functions separately by commodity (Hasenkamp 1976; Hayami and Ruttan 1985). These functions use output and input prices and resource levels (land, labour, capital) as dependent variables. However, in the case of China two special difficulties impede the applicability of this approach. First, despite the decollectivisation in the 1980s, farm decision making has not yet become a fully family affair, and various rules and regulations are still in effect which do not find an expression in farm-gate prices and are not formally recorded. The data used in our study refers to the year 1990 when even more decisions were made at village government level than is the case now. Second, the only available output price data are (weighted average) state procurement prices for major crops at provincial and national levels and there are no published input price data available. To overcome these obstacles, the transformation function had to be estimated directly in its primal form. Yet, to investigate the degree to which the prevailing allocations could be interpreted as resulting from a profit maximisation model, we compute 


\section{Dilemmas of China's Growth in the Twenty-First Century}

and compare the implicit prices that would support observed allocations under profit maximisation.

\section{Transformation of the agricultural sector during 1979-99}

In 1979, China initiated a dramatic reform of the institutional structure in its agricultural sector. From collective-based agriculture, changes were made towards a system in which the individual farm household became the basic decision-making unit with respect to inputs and most outputs. As a rule, the new family farms are small and fragmented and depend heavily on irrigation, which induces Chinese farmers to save land and capital and to opt for highly labour-intensive practices. What follows is a review of the main elements of this transformation process.

\section{Institutional arrangement of China's family farms in the post- reform era}

During the period 1979-83 collective farming was replaced by the household responsibility system (HRS). Under the HRS, individual households in a village are granted the right to use the farmland for 15-30 years, whereas the village community, via its government, retains other rights associated with the ownership of the land. This land tenure system constitutes a two-tier system with use rights vested in individual households and the ownership rights in the village community (Dong 1996; Kung 1995).

Unlike in the previous collective system, under the new land tenure system farm households are independent production and accounting units. Each household can independently organise its production and exercise control over outputs and production. Most importantly, control rights over residual benefits are assigned to individual households. A fraction of the crop is still sold to the state via state procurement requirements at prices below the free market level, and another fraction is delivered to the village government as payment for rent or taxes and as a contribution to the village welfare fund and accumulation fund. The remainder is left to the households for consumption, saving and possibly to sell in the free market. The right to use land also entails an obligation to contribute labour for the maintenance and construction of public infrastructure. The function of the village governments in the HRS includes the management of land contracts, the maintenance of irrigation systems and the provision of agricultural services such as large farm machinery, product processing, marketing and technological advice and assistance (Lin 1997; Wen 1993; World Bank 1985).

When the HRS was introduced, collectively owned land was initially 


\section{Towards estimating agricultural production relations for China}

contracted to each household in short leases of one to three years. In the distribution of land, the guiding principle was generally egalitarianism. Most villages have leased land to their member households strictly on the basis of family size rather than intra-household labour availability. Moreover, at the initial distribution, land was first classified into different grades. Thus, a typical farm household would contract 0.56 hectare of land fragmented into 9.7 tracts (Dong 1996; Lin 1997). Eventually the one to three-year contract was found to discourage investment in land improvement and soil fertility conservation. Further reforms were initiated and the duration of the contract was extended to 15-30 years. As a result, various models of the land tenure system have evolved in different regions as an adaptation to local needs and conditions. ${ }^{5}$

\section{Pricing and marketing of agricultural products}

During the establishment of the HRS, increasing emphasis was given to market mechanisms for guiding production decisions in the agricultural sector, although central planning was still deemed essential. The number of planned product categories and mandatory targets was reduced from 21 and 31 in 1978 to 16 and 20, respectively, in 1981, and reduced further to 13 in 1982. Moreover, restrictions on the interregional trade of agricultural products by private traders were gradually loosened. Cropping patterns that fit local conditions and exploited comparative advantages were encouraged. As a consequence, both cropping patterns and intensity changed substantially between 1978 and 1984. The sown acreage of cash crops increased from 9.6 per cent of the total in 1978 to 13.4 per cent in 1984 , and the multiple-cropping index declined from 151 to 147 (Lin 1997:Table 3).

The second round of market reforms was initiated in 1985. The central government announced that the state would no longer set any mandatory production plans in agriculture and that the obligatory procurement quotas were to be replaced by purchasing contracts between the state and farmers (Central Committee of CCP 1985). Although the progress of this market reform has been slower and less smooth than expected, the market freedom enjoyed by Chinese farmers has significantly increased. In the early 1990s about twothirds of China's marketable cereal production was purchased or sold in the form of free retails or wholesales at prices determined by market forces. The gap between market prices and quota prices has gradually narrowed although the pace has been slow and uneven. The production and marketing of vegetables, fruits and most cash crops have been fully liberalised since 1985 .

\section{Dependence on irrigation}

About half of China's farmland has been under some form of irrigation since the 1980 s. $^{6}$ The irrigated land produces about 70 per cent of grain output, 


\section{Dilemmas of China's Growth in the Twenty-First Century}

most of cotton, cash crops and vegetables. Thus, heavy dependence on irrigation is another unique feature of China's agriculture. This contrasts sharply with the situation in other major agricultural world regions. For instance, in the United States only one-tenth of the grain output comes from irrigated land (Brown and Halweil 1998). While the major share of irrigation water has been delivered to the fields by gravity irrigation with the help of dams, reservoirs, canals and irrigation systems, an increasing proportion of irrigation water in China is being supplied by diesel and electric pumps. Machine-powered irrigation accounted for one-quarter of the total irrigated area in 1965, increasing to two-thirds in 1993 (SSB 1993: 349; Ministry of Water Conservation 1994). As a consequence, irrigation equipment has been accounting for a large fraction of the total power consumed by agricultural machinery since the $1980 \mathrm{~s}$.

\section{Labour-intensive production}

It is generally accepted that land is an extremely scarce factor in China's agriculture, capital is limited and labour is relatively abundant (Lindert 1999; Wang, 1998; Dazhong 1993). Although the percentage of the labour force engaged in agriculture has gradually fallen from 93.5 per cent in 1952 to 56.4 per cent in 1993, the total number of agricultural workers doubled during the same period due to rapid population growth (the population increased from 173 million in 1952 to 374 million in 1993). This was despite the impact of rapid expansion in the rural industrial sector which has created employment for more than 120 million rural workers since 1992. The growth in the absolute number of farm workers in the cropping sector persisted until 1984, and this trend persisted in 1993 for the agricultural sector as a whole (Lin 1992:Table 4; SSB 1997:94, 400). In 1990, the average family farm managed only 0.42 hectares of farmland but had 1.73 labourers engaging in agriculture (Ministry of Agriculture 1991).

Constrained by the unfavourable land-labour ratio, Chinese peasants have only been able to adopt labour-intensive, land-saving and yield-increasing technologies. These include the intensive use of organic and chemical fertilisers, irrigation development, the use of plastic film to cover fields, the rapid adoption of new crop varieties like hybrid rice, sophisticated cropping systems and high levels of multiple cropping. Most of the land-saving technologies increase the need for the application of nutrients and other farm inputs.

Organic fertiliser has always been central to traditional, small-scale Chinese farming. Farmers commonly use a wide variety of organic fertilisers, including night soil (that is, human excrements), animal manure, oil cakes, decomposed grasses and household wastes, river and lake sludge and various green manures. Night soil and animal manure have been the most important sources due to their high nutrient content and low cost. ${ }^{7}$ 


\section{Towards estimating agricultural production relations for China}

Chemical fertilisers have increasingly been used to improve crop yields owing to the rapid growth of domestic fertiliser production capacity and of fertiliser imports. Chemical fertiliser use in China has quadrupled since 1978. Since the early 1990s, China has emerged as the largest consumer, the second largest producer and as a major importer of chemical fertilisers in the world (FAO; SSB 1989-97). However, the average application of chemical fertiliser has remained modest, at 155 kilograms of nutrients per hectare in 1995, which is below the average level of East Asian developing countries and far below that in Japan and South Korea. ${ }^{8}$ According to estimates of the World Bank (1997:16), fertiliser applied in 1995, with an estimated value of 125 billion yuan, was the major cash input in crop production. The rapidly increasing application of chemical fertiliser has been identified by many as a key factor contributing to the significant productivity growth in China's agricultural sector over the past three decades. Many studies suggest that the overall yield response to chemical fertiliser has been significant (Kueh 1984; McMillan et al. 1989; Halbrendt and Gempesaw 1990; Lin 1992), partly through mutual reinforcement between the increasing application of chemical fertiliser and the adoption of new crop varieties which are responsive to chemical fertilisers.

Two recent quantitative estimations suggest that chemical fertiliser application increased much faster than the use of organic fertiliser since the early 1970s and had become the dominant nutrient source by 1988 (Agricultural Academy of China 1995:Chapter 8) or 1982 (Wang et al. 1996). However, because of the low quality and inefficient methods of application of chemical fertiliser, about half the nitrogen applied to irrigated land is lost to evaporation (World Bank 1997:18), leaching and emissions and this leaves much room for efficiency gains.

Also of note is that organic fertiliser is more than merely a substitute for chemical macro-nutrients. With its high content of organic matter and a wide range of crop macro and micro-nutrients, organic fertiliser improves soil structure and fertility in the long run. Thus, it is believed that organic fertiliser should complement chemical fertiliser and improve its effectiveness. Organic fertiliser is also able to be applied to rainfed land without preconditions, whereas the application of chemical fertiliser is constrained by the necessity of a timely water supply. Finally, the traditionally careful use of organic fertilisers made the transition to chemical fertilisers relatively smooth and easy in China in the 1960s and 1970s (Stone and Desai 1989).

\section{Crop-mix index and input response function}

We follow Keyzer (1998) in our specification of the agricultural production relationships. We postulate a transformation function that is separable in outputs 


\section{Dilemmas of China's Growth in the Twenty-First Century}

and inputs, with a crop-mix index for outputs and a response function for inputs. The crop-mix index is in CES form and the input response is specified as a generalised version of the common Mitscherlich-Baule (MB) yield function, whose maximal attainable output is obtained from an agro-ecological zone assessment. The input response distinguishes two types of land: irrigated and rainfed. Their yield potentials and cropping practices differ significantly. However, as is usual in agricultural sector modelling, the data on inputs is not differentiated by type of land use or by crop, and since data on crop output is not land-use type specific, we cannot estimate a transformation function for each land-type or crop separately. Instead we must be satisfied with the estimation of a single transformation function applied for all crops and landuse types.

Let the subscript $l$ denote observations (that is more than 2,000 counties in our case), $\mathrm{Y}$ a $l \times \mathrm{C}$ vector of outputs, $\mathrm{V}$ a $l \times \mathrm{K}$ vector of non-land inputs, and $A$ a $l \times S$ vector of land uses with $S$ different land quality types. The vector of natural conditions, including climate, soil and terrain characteristics, is denoted by $\mathrm{x}$. We postulate a transformation function $\mathrm{T}(\mathrm{Y},-\mathrm{V},-\mathrm{A}, \mathrm{x})$ that is taken to be quasi-convex, continuously differentiable, non-decreasing in ( $Y$, $\mathrm{V},-\mathrm{A})$ and linear homogeneous in $(\mathrm{V}, \mathrm{A})$. The function $\mathrm{T}$ describes all possible input-output combinations. To ease estimation, separability is assumed between inputs and outputs

$$
T(Y,-V,-A, x)=Q(Y)-G(V, A ; x)
$$

where $Q(Y)$ is the crop-mix index, and $G(V, A ; x)$ the input response function. Function $Q(Y)$ is taken to be linear homogeneous, convex, nondecreasing and continuously differentiable, and $G(V, A ; x)$ is linear homogeneous, concave and non-decreasing in $(\mathrm{V}, \mathrm{A})$ and continuously differentiable. This implies that the transformation function $T$ is convex and non-increasing in net outputs. The interpretation of this transformation function is as follows: under natural conditions $\mathrm{x}$, the given input and land availabilities $(\mathrm{V}, \mathrm{A})$ make it possible to produce a quantity $\mathrm{G}$ of the aggregate production index $Q$, with any crop mix such that $Q(Y)=G$.

The input and output variables are measured in quantity terms and were compiled per county. As discussed earlier, the transformation function is estimated in primal form rather than in the dual form with separate cropspecific supply functions, for two reasons. First, profit maximisation may not be the relevant behavioural criterion for Chinese agriculture, and price data cannot capture the variability at county level since they are only available at provincial level and measured as a mix of procurement prices and free market prices. The estimation is cross-section over counties, in volumes per unit area (represented by the corresponding lower case characters).

That is $\mathrm{q}(\mathrm{y})=\mathrm{g}(\mathrm{v}, \mathrm{a} ; \mathrm{x})+\varepsilon$ 


\section{Towards estimating agricultural production relations for China}

where $\varepsilon$ denotes the error term, assumed to be independently and normally distributed.

\section{Crop-mix output index}

The crop-mix output index $Q(Y)$ is specified as a convex function with constant elasticity-of-substitution (CES)

$$
Q\left(\mathrm{Y}_{\ell}\right)=\left(\sum_{\mathrm{c}}\left(\alpha_{\mathrm{c}} Y_{\ell_{c}}\right)^{\alpha_{0}}\right)^{1 / \alpha_{0}}
$$

where $\alpha_{c} \geq 0$ and $\alpha_{0}>1$. The curvature of the output function, or the (direct) elasticity of transformation between any two outputs, equals $1 /\left(1-\alpha_{0}\right)$. The restriction $\alpha_{0}>1$ guarantees the CES function to be convex.

The specification also needs to be flexible in order to account for differences in cropping patterns across counties (in case, say, in a county only ten of the sixteen crops are being grown. This could be incorporated in various ways. One way would be to drop the crops from the crop-mix index, while scaling up the coefficients for the remaining crops in Equation 8.3 through an additional parameter. In doing this however, we face the problem that in China the number of crop-mixes often outnumbers the observations and two to four crops often cover about two-thirds of the total production value. To deal with this problem we introduce a distinction between major and minor absent crops, and associate a limited number of scaling factors to the production function of a particular county, depending on the number and importance of the absent crops. Consequently, Equation 8.3 becomes

$$
Q\left(\mathrm{Y}_{\ell}\right)=\left(1+\sum_{m} \mu_{m} M_{\ell m}\right)\left(\sum_{\mathrm{c} \in C_{\ell}}\left(\alpha_{\mathrm{c}} Y_{\ell c}\right)^{\alpha_{0}}\right)^{1 / \alpha_{0}}
$$

where $\mu_{m}$ is an estimated scaling factor, $M_{l m}$ is a zero-one dummy that associates the county to a particular scaling factor and $\mathrm{C}_{l}$ is the set for which $Y_{l c}>0$. Each county has at most one non-zero crop-mix dummy.

\section{Input response function}

The input response function combines the information obtained from biophysical assessments with the statistical data available at county level. It is specified as

$$
Q_{\ell}=f\left(\mathrm{~V}_{\ell}, H\left(A_{\ell}\right)\right) N\left(A_{\ell}, \bar{y}_{\ell}\left(x_{\ell}\right)\right)
$$

where $f() N.($.$) is a generalised Mitscherlich-Baule specification following$ Keyzer (1998), and $H($.$) and N($.$) are the aggregate area and potential output$ index, respectively, which are specified as

$$
\begin{aligned}
& H_{\ell}\left(\mathrm{A}_{\ell} ; \delta\right)=\sum \delta_{s} \mathrm{~A}_{\ell \mathrm{s}} \\
& N_{\ell}\left(\mathrm{A}_{\ell}, \overline{\mathrm{y}}_{\ell}\left(\mathrm{x}_{\ell}\right)^{s} ; \delta\right)=H_{\ell}\left(\mathrm{A}_{\ell} ; \delta\right) \bar{y}_{\ell}\left(\mathrm{x}_{\ell}\right)
\end{aligned}
$$




\section{Dilemmas of China's Growth in the Twenty-First Century}

with $\bar{y}_{\ell}\left(x_{\ell}\right)$ denoting the maximal attainable yield for given agro-ecological conditions $\mathrm{x}_{1}$. This potential yield $\bar{y}_{\ell}\left(x_{\ell}\right)$ is calculated as the maximal attainable production $\bar{Y}_{\ell}\left(x_{\ell}\right)$ divided by land index $H_{\ell}$. Parameter $\delta_{s}$ is preset and was not estimated. The input response function $f($.$) in Equation 8.5$ is specified in product form, to allow for different input groups. The functional form is

$$
f\left(V_{\ell}, H\left(\mathrm{~A}_{\ell}\right)\right)=\prod_{j} f_{j}\left(V_{\ell}, H_{\ell} ; \beta_{j}, \gamma, \rho_{j}\right)^{\theta_{j}}
$$

with

$$
\mathrm{f}_{\mathrm{j}}=1-\exp \left[-\beta_{\mathrm{j}}-w_{j}\left(\mathrm{~V}_{\ell}, \mathrm{H}\left(\mathrm{A}_{\ell} ; \delta\right) ; \gamma, \rho_{j}\right)\right]
$$

where $f_{j}$ is the $j^{\text {th }}$ component of a Mitscherlich-Baule (MB) yield function and its exponent $\theta_{j}>0$ is such that $\sum_{j} \theta_{j}=1$. This parameter $\theta_{j}$ avoids the increasing returns that would result from the standard MB-form with $\theta_{i}=1$. In addition, a nested structure is assumed for inputs so as to ease the nonlinear estimation. In Equations 8.8 and 8.9, index $j$ stands for two categories of inputs, power and nutrients. Power consists of labour and agricultural machinery. Nutrients include chemical and organic fertilisers. For both categories we assume a CES form, denoted by $w_{j}$.

$$
w_{j}\left(\mathrm{~V}_{\ell}, \mathrm{H}\left(\mathrm{A}_{\ell} ; \delta\right) ; \gamma, \rho_{j}\right)=\left(\sum_{\mathrm{k} \in \mathrm{j}} \gamma_{k}\left(\frac{\mathrm{V}_{\ell \mathrm{k}}}{H_{\ell}}\right)^{\rho_{\mathrm{j}}}\right)^{1 / \rho_{\mathrm{j}}}
$$

with $\gamma_{k} \geq 0$ and $\rho_{j} \leq 1$ ensuring concavity of w(.). Input response function (Equation 8.5) is linear homogeneous, globally concave and non-decreasing in $(\mathrm{V}, \mathrm{A})$ and continuously differentiable.

The biophysical diversity across China is reflected in the potential yield $\bar{y}_{\ell}\left(x_{\ell}\right)$ as will be explained later. However, cropping possibilities vary widely across China and also within the estimated regions, ranging from single cropping to triple rice cropping. The maximal attainable yield $\bar{y}_{\ell}\left(x_{\ell}\right)$ alone is not sufficient to capture this variability. To account for these differences, cropping system zone variables $Z_{\ell z}$ are introduced, where the subscript $z$ indicates the cropping system zone. If for irrigated conditions a county is located in cropping system zone $\mathrm{z}$, the value of the related variable is one or zero if this is not the case. Equation 8.5 then becomes

$$
Q_{\ell}=Z_{z} f\left(\mathrm{~V}_{\ell}, H\left(A_{\ell}\right)\right) N\left(A_{\ell}, \bar{y}_{\ell}\left(x_{\ell}\right)\right)
$$

with

$$
Z_{z}=\sum_{z} \zeta_{z} Z_{\ell z}
$$

The outputs in Equation 8.4 and the potential production in Equation 8.5 are measured in different units. $Y_{\ell c}$ is given in metric tonnes of produce, 


\section{Towards estimating agricultural production relations for China}

while the potential is given as cereal equivalent in metric tonnes of economic dry matter. Harmonisation of the dimensions is restored via the crop and county specific parameter ratio $\alpha_{c}\left(1+\mu_{m} M_{\ell m}\right) / \zeta_{z} Z_{\ell z}$.

\section{Computing implicit prices for aggregation}

The transformation function enters the land use change (LUC) model for China after an aggregation procedure from county to region. Our approach is to assume implicit profit maximisation at implicit prices. These are the prices that would support the observed crop and input allocations under profit maximisation. We interpret the gap between these prices and average market prices in the cities as processing margins, which we use in the aggregation procedure from county to region. Clearly, this procedure needs further empirical justification and we will show that the resulting margins have a meaningful interpretation. Despite the institutional peculiarities in China we can view the decisions concerning allocation as being based on profit maximisation at prices governed by institutionally determined wedges.

Assuming profit maximisation subject to the separable transformation function (Equation 8.1) ensures separability between output and input decisions. The farmer determines the crop-mix so as to maximise the revenue corresponding to a given value of the index $\mathrm{Q}$, while choosing the level of inputs $V$ and corresponding aggregate output $Q$ so as to maximise his revenue, at given prices of $\mathrm{V}$ and $\mathrm{Q}$.

Thus, the crop-mix problem of the revenue maximizing farmer with given output index $\overline{\mathrm{Q}}_{\ell}$ is stated as

$$
\begin{array}{ll}
\max _{Y_{\ell c} \geq 0} & \sum_{c \in C_{\ell}} p_{\ell c} Y_{\ell c} \\
s . t & \mathrm{Q}\left(\mathrm{Y}_{\ell}\right)=\bar{Q}_{\ell}
\end{array}
$$

with $\mathrm{p}_{l c}$ as the price of crop $c$ in county $l$. The Lagrangean of this problem is

$$
\mathrm{L}=\sum_{c \in C_{\ell}} p_{\ell c} Y_{\ell c}-\bar{P}_{\ell}\left(\mathrm{Q}\left(\mathrm{Y}_{\ell}\right)-\bar{Q}_{\ell}\right)
$$

where the Lagrangean multiplier is the county level price index $\bar{P}_{\ell}$ since the function $\mathrm{Q}\left(\mathrm{Y}_{k}\right)$ has constant returns to scale. The first order conditions of this problem determine the implicit (shadow) prices of crop $c \in \mathrm{C}_{1}$

$$
p_{\ell c}=\bar{P}_{\ell} \frac{\partial Q\left(\mathrm{Y}_{\ell}\right)}{\partial Y_{\ell c}}=\frac{\bar{P}_{\ell} \bar{Q}_{\ell}}{Y_{\ell c}} \frac{\left(\alpha_{c} \mathrm{Y}_{\ell c}\right)^{\alpha_{0}}}{\sum_{c^{\prime}}\left(\alpha_{\mathrm{c}^{\prime}} \mathrm{Y}_{\ell c^{\prime}}\right)^{\alpha_{0}}}
$$

For the base year the county level price index $\bar{P}_{\ell}$ has been calculated from provincial and national prices and county level production data (see Appendix 8.1). In simulation runs with endogenous crop prices $p_{\ell c}$ the index is calculated 


\section{Dilemmas of China's Growth in the Twenty-First Century}

as $P_{\ell}=\frac{1}{\left(1+\sum_{m} \mu_{m} M_{\ell m}\right)}\left(\sum_{c \in C_{\ell}}\left(\frac{p_{\ell c}}{\alpha_{c}}\right)^{\sigma}\right)^{\frac{1}{\sigma}}$

with $\sigma=\frac{\alpha_{0}}{\alpha_{0}-1}$.

The county specific relation between the base year price index and the obtained under the maximising producer assumption becomes

$$
\overline{P_{\ell}}=P_{\ell}\left(1+\varepsilon_{\ell}^{p}\right)=P_{\ell}\left(1+\frac{\overline{P_{\ell}}-P_{\ell}}{P_{\ell}}\right)
$$

In simulation runs the estimated price index can replace the 'observed' index.

Finally, for the input side the restricted profit maximisation problem becomes

$$
\max _{V_{\ell k} \geq 0, A_{\ell s} \geq 0} \bar{P}_{\ell} G\left(V_{\ell}, \mathrm{A}_{\ell}\right)-\sum_{k} p_{\ell k} V_{\ell k}-\sum_{s} p_{\ell s} A_{\ell s}
$$

The first order condition with respect to input $k$ of group $j$ gives the marginal productivity

$$
p_{\ell k}=\bar{P}_{\ell} \frac{\partial G\left(\mathrm{~V}_{\ell}, \mathrm{A}_{\ell}\right)}{\partial V_{\ell k}}=\bar{P}_{\ell} \frac{\partial g\left(v_{\ell k}\right)}{\partial v_{\ell k}}
$$

with $v_{\ell k}=V_{\ell k} / H_{\ell}$ and

$$
\frac{\partial g\left(v_{\ell k}\right)}{\partial v_{\ell k}}=g_{\ell} \theta_{j} \frac{1-f_{\ell j}}{f_{\ell j}} w_{\ell j}^{1-\rho_{j}} \gamma_{k} v_{\ell k}{ }^{\rho_{j}-1}
$$

For land-use type $s$ the marginal productivity is

$$
\begin{aligned}
\mathrm{p}_{\ell \mathrm{s}} & =\overline{\mathrm{P}}_{\ell} \frac{\partial \mathrm{G}\left(\mathrm{V}_{\ell}, \mathrm{A}_{\ell}\right)}{\partial \mathrm{A}_{\ell \mathrm{s}}}=\overline{\mathrm{P}}_{\ell}\left(\mathrm{f}_{\ell} \frac{\partial \mathrm{N}\left(\mathrm{A}_{\ell s}\right)}{\partial \mathrm{A}_{\ell s}}+\mathrm{N}_{\ell} \frac{\partial \mathrm{f}\left(\mathrm{V}_{\ell}, \mathrm{A}_{\ell s}\right)}{\partial \mathrm{A}_{\ell s}}\right) \\
& =\bar{P}_{\ell} \delta_{s} g\left(\mathrm{v}_{\ell}\right)\left(1-\frac{\partial g\left(\mathrm{v}_{\ell}\right)}{\partial \mathrm{v}_{\ell}} \frac{\mathrm{v}_{\ell}}{g\left(\mathrm{v}_{\ell}\right)}\right)
\end{aligned}
$$

where

$$
\frac{\partial g\left(\mathrm{v}_{\ell}\right)}{\partial \mathrm{v}_{\ell}} \frac{\mathrm{v}_{\ell}}{g\left(\mathrm{v}_{\ell}\right)}=\sum_{j} \theta_{j} \frac{1-f_{\ell j}}{f_{\ell j}} w_{\ell j}
$$

and $f_{\ell j}$ and $w_{\ell j}$ are the same as defined by Equations 8.9 and 8.10 . 


\section{Data-sources, adjustments and qualifications}

Despite major improvements in the quality and availability of relevant statistics for China, various procedures had to be applied to scrutinise data, fill data gaps and define proxy variables.

\section{Crop outputs and procurement prices}

The total annual output of grain, cotton and oilseeds is available at county level (SSB and CDR 1996). The published data were matched with county administrative codes as used in the LUC Project's database of China. Also available are outpur data and sown areas of wheat, rice, maize, sorghum, millet, other starchy crops, potato and other root crops, soybean, oilseeds, cotton, sugar beet, sugarcane, fiber crops, tobacco, tea and fruit for 1989 but not for 1990. These data were compiled by the State Land Administration and provided to FAO. The year 1990 is representative of the average conditions of Chinese cropping agriculture during the period 1985-95. As the 1989 crop was fairly poor due to weather conditions, we use data for 1990 whenever possible. Consequently, we had to disaggregate the data for grains in 1990 on the basis of crop-pattern distribution available for 1989. According to Chinese statistics, the aggregate termed grains include wheat, rice, maize, sorghum, millet, other starchy crops, potato and other root crops and soybean (five kilograms of potato and other root crops are counted as one kilogram of grain; all other commodities have a conversion factor of unity). For sugarcane, fiber crops, tobacco, tea and fruits, the 1989 outputs had to be used.

Thus, crop outputs in 1990 were estimated as

$$
\mathrm{q}_{\mathrm{c}}^{90}=\mathrm{G}^{90} \cdot \frac{\mathrm{q}_{\mathrm{c}}^{89}}{\mathrm{G}^{89}}
$$

where $G^{t}$ is total grain output in year $t$ and $q_{c}^{t}$ is crop-specific output measured in grain equivalent. In the case of vegetables, only estimates of sown areas at the county level for 1989 were available, and then there was no available output data for any year. The national average yield of 20.9 tonnes per hectare in 1989 was used to calculate vegetable output at county level (Xie and Keijing 1994:103).

Procurement prices at both provincial and national levels for wheat, rice, maize, sorghum, millet, soybean, oilseeds, cotton, sugarcane, fiber crops, tobacco, tea and fruit were extracted from The Yearbook of Price Statistics of China 1992 (SSB 1992b:302-65). The procurement price for a crop is a quantity-share-weighted mean of quota prices, negotiated prices and free market 


\section{Dilemmas of China's Growth in the Twenty-First Century}

prices. The procurement of commodities is not only done by government agencies, but also enterprises, social organisations and trade companies. There is no price data for Hainan province in this Yearbook. Prices in Guangdong were used as proxies for Hainan, in view of the fact that Hainan province had been a prefecture of Guangdong until 1988. No price data are available for the aggregate of other starchy crops. The price of maize is used as a proxy in each province following the information in the national price data for China listed in the FAO-AGROSTAT database. Again with reference to FAO-AGROSTAT, one-third of wheat price is used as a proxy for the price of potato and other root crops in each province.

Prices of vegetables were compiled from Nationwide Data on Costs and Revenues of Agricultural Products 1991 (Eight Ministries and Bureaus 1991). The prices listed in this publication are the free market selling prices of major vegetables shown for selected major cities (typically the provincial capital city) in most of the provinces. Representative vegetables for each province were selected and the representative price for the vegetable category is the arithmetic mean of the various prices.

With the steps described in the previous paragraphs price data could be obtained for all of the major crops of each province. However, the price information for some minor crops was still missing and these are actually the main crops in some counties. To fill these gaps a corresponding price was used from one of the neighbouring provinces with similar production conditions. When no such province was available the national average price was used as a proxy.

In the compilation of the initial output index $Q$, the provincial prices were applied directly to the county level, ignoring all price differences across counties within each province.

\section{Non-land and land inputs}

Data on non-land inputs used in the broad agricultural sector at county level are available in the LUC Project for various years between 1985-94. They include agricultural labour force, total power of agricultural machinery, total number of large animals and the chemical fertiliser applied. We will only discuss the 1990 data since these were used in estimation. A data problem arises from the fact that in Chinese statistics, broad agriculture consists of farming, forestry, animal husbandry, fisheries and sideline production. We attribute non-land inputs to the crop sector based on the share of crop agriculture in broad agriculture. The total output value of broad agriculture is available at the county level. The availability of crop output enables us to calculate the total output value of cropping agriculture for each county by straight aggregation over crops valued at provincial prices. The resulting shares are applied to the agricultural labour force and the power of agricultural machinery. ${ }^{9}$ 


\section{Towards estimating agricultural production relations for China}

Two comments need to be made. First, the approach is questionable for counties where the share of cropping agriculture is minor or where agricultural workers or machinery are in fact used for non-agricultural activities. In some (sub) urban counties the number of agricultural workers per hectare of agricultural land is extremely high (more than ten). Machine power per hectare is likewise biased due to the fact that transport vehicles and other processing machineries are included in the statistics. Nonetheless these counties were initially included in the estimations. After the first round, some of the counties biased the estimation substantially and these observations were dropped. Secondly, prices are at the provincial level and consequently the variability at county level depends on quantities alone.

Whereas chemical fertiliser applied can safely be attributed to crop farming rather than to forests or pastures, organic fertiliser data can only be derived by imputation. We follow the approach in Wen (1993:Tables 4 and 5) and assume that

- one person produces 0.5 tonnes of night soil per year on average. In 1990 , the utilisation rates of night soil in the rural and urban areas were 0.8 and 0.4 , respectively. The nutrient content rate of night soil was 0.011 , or 1.1 per cent

- a large animal produces 7.7 tonnes of manure per year on average. The utilisation rate is 0.8 and the nutrient content rate is 0.0102

- hog manure is assumed to be 2 tonnes per animal per year, with a utilisation rate of 0.8 and a nutrient content rate of 0.014 .

No systematic data is available on other sources of organic fertiliser such as green fertiliser, oil cake, compost, and mud and pond manure. The resulting estimate of the national total at 17.5 million tonnes of organic fertiliser supply is six million tonnes lower than Wen's 1989 figure, but seven million tons higher than the corresponding 1991 figure given by the Agricultural Academy of China (1995:95). In some counties, where animal husbandry plays a key role, the manure of large animals may dominate in total organic fertiliser and animal manure is often used as fuel rather than as plant nutrient. Hence, to avoid unrealistically high estimates of organic fertiliser application in these counties, we impose a ceiling of 120 tonnes of raw organic fertiliser manageable per worker per year (Wiemer 1994), which is equivalent to about 1.2 tonnes of nutrient content.

For farmland, we use the county level data on total cultivated land areas and irrigated land compiled by Chinas State Land Administration (SLA). The national total of cultivated land areas obtained by summation over counties is some 135 million hectares, which is about 40 million hectares higher than the corresponding national figure published in the Statistical Yearbook of China (SSB 1991:314). However, this is still consistent with the figure recently 


\section{Dilemmas of China's Growth in the Twenty-First Century}

compiled by the SLA based on a detailed land survey (see Fischer et al. 1998). ${ }^{10}$ In addition to statistical data, the LUC Project database includes several digital coverages for China, including climate, land use, vegetation, altitude and soils. These were compiled, re-organised and edited jointly with the Chinese collaborators in the LUC Project to provide a basis for biophysical assessments of surface hydrology, vegetation distribution and for estimating potential yields of major crops. ${ }^{11}$ Although these maps provide useful spatial information for land-use research, their scale is insufficient to derive accurate overlays of the actual farmland in 1990 with soil and terrain resources for differentiating land quality types among actual farmland. Hence, the land quality types (index $s$ ) applied at county level currently only distinguish irrigated and rainfed land.

In actual farming practice, the distinction between irrigated and rainfed land is not as strict as suggested by the statistical figures. In some areas, when rainfall is in time for cropping and is in adequate amounts, irrigation is unnecessary and the differentiation between irrigated and rainfed land becomes unimportant. Conversely, when the water shortage is severe, irrigation may be impossible despite existing irrigation facilities.

\section{Potential yields}

Biophysical reality enters the input-output relationships through a potential output index $N(A, \bar{y}(x)$ (Equation 8.7) and the cropping system zone index $Z_{l}$ (Equation 8.12) and involves the estimation of potential production $\overline{\mathrm{Y}}_{\ell, \mathrm{S}}(\mathrm{x})$ by county and land-use type.

After conducting a detailed agro-ecological zones (AEZ) assessment across counties in China, the land suitability and potential yields were estimated for 27 major crops, differentiated into some 150 crop types. This evaluation was carried out both for irrigated and rainfed conditions using the methodology described in Fischer et al. (2000). To arrive at the potential yields to be used in the production function (Equation 8.5), a suitable aggregation had to be performed in three steps:

- classification of each $5 \times 5 \mathrm{~km}$ grid-cell of the LUC land resources inventory for China into one of seven major multiple cropping zones

- classification of cereal crop types into eight crop groups according to crop cycle length and thermal crop requirements

- aggregation of results at $5 \times 5 \mathrm{~km}$ grid-cells to county administrative units.

The calculations and aggregations were performed separately for both rainfed and irrigated conditions. As an example, the multiple cropping zones applicable under irrigation conditions are shown in Figure 8.1.

In zone one, thermal conditions allow for only one crop to be grown per year. The potential yields are determined by the highest simulated yield among 


\section{Towards estimating agricultural production relations for China}

all suitable cereal crop types under irrigated and rainfed conditions, respectively. In zone two, temperature profiles permit cultivation of two short-cycle crops or relay cropping systems. Examples include wheat and millet grown in sequence, or wheat or maize relay crops. Yields are calculated separately for crops adapted to cool and to moderately warm or warm conditions. Potential yields at county level are constructed from these pools according to the observed multi-cropping index $(\mathrm{MCI})$. Zone three is a typical double-cropping zone with wheat or barley grown as a winter crop (including a dormancy period) and crops such as maize, soybean or sweet potato grown in the warm season. Potential annual yields are constructed from these two pools.

Zone four has double cropping similar to the previous zone, except that main summer crops such as rice or cotton demand more heat. Zone five is generally found south of the Yangtse, and permits limited triple cropping consisting of two rice crops and, for instance, green manure. The annual temperature profile is usually insufficient for growing three full crops. When the observed MCI does not exceed 2.0, the combination of the best suitable crops during the cooler and warmer seasons of the year defines the potential annual yield. The more the observed MCI exceeds 2.0 , the less applicable are crop types with long growth cycles, because of the time limitations. When the $\mathrm{MCI}$ approaches 3.0, only crop types requiring 120 days or less are considered when calculating annual output. Zone six occurs in southern China and allows three sequential crops to be grown. A typical example is the cropping system with one crop of winter wheat and two rice crops grown in spring to autumn. In this case, only short-cycle crops can be considered.

Finally, zone seven delineates the most southern part of China where tropical conditions prevail and allows three crops to grow that are well adapted to warm conditions, such as rice. In our calculation, this condition is satisfied when the growing season is year-round and annual accumulated temperature (above $10^{\circ} \mathrm{C}$ ) exceeds 7,000 degree-days. Only crop types requiring less than 120 days until harvest are considered when the MCI exceeds 3.0.

Table 8.1 shows the number of counties in each cropping system zone under irrigated conditions to be used in the estimation. If there are only very few counties in a cropping system zone of a particular region the observations have been added to the adjacent zone. Figure 8.2 summarises the results of the biophysical assessment weighted by actual shares of irrigated and rainfed cultivated land in each county.

\section{Crop mix}

Not all of the 16 crops considered are grown in each county or even in each region. To capture this aspect, scaling parameters were introduced into the crop-mix index function (Equation 8.4). Table 8.2 gives the shares of each 


\section{Figure 8.1 Multiple cropping zones under irrigated conditions}

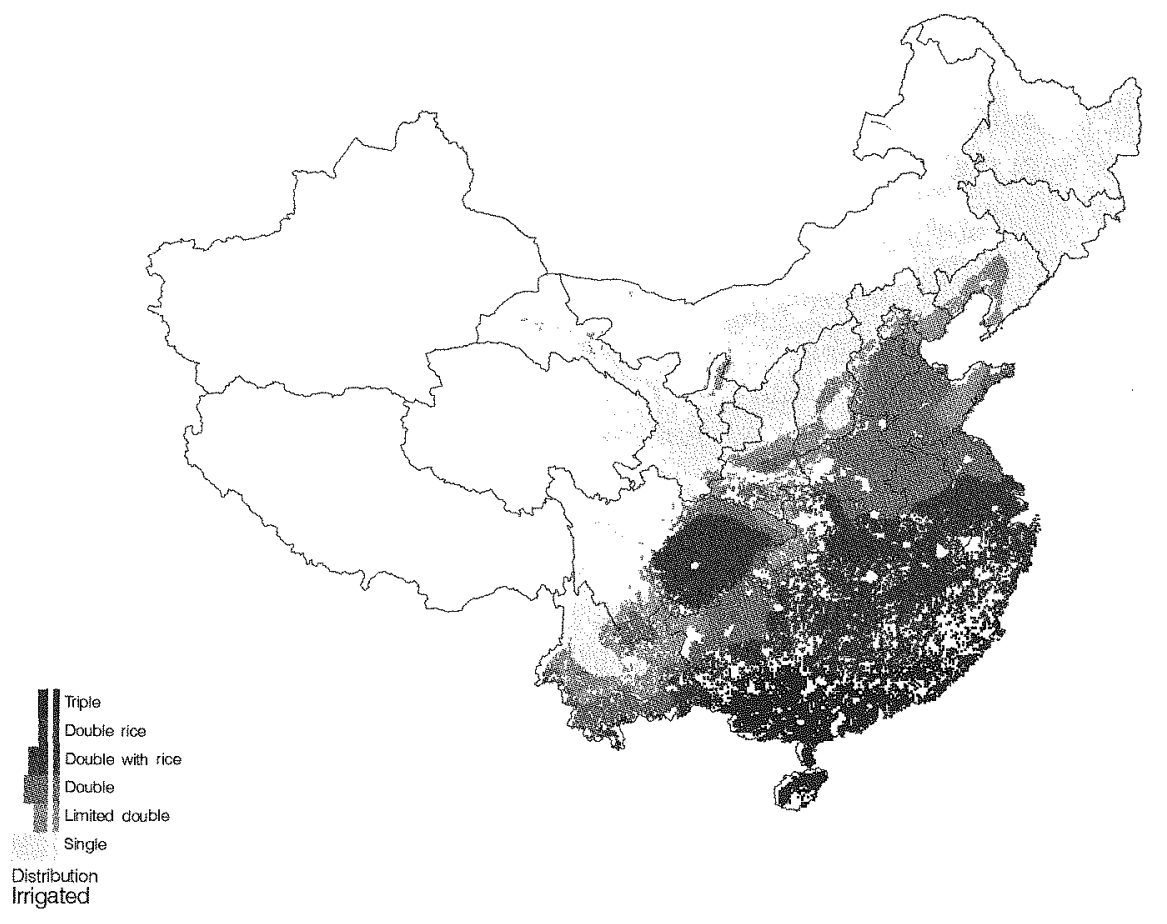

Table 8.1

Number of counties per cropping system zone by region

\begin{tabular}{|c|c|c|c|c|c|c|c|}
\hline & North & $\begin{array}{l}\text { North } \\
\text { East }\end{array}$ & East & $\begin{array}{l}\text { Region } \\
\text { Central }\end{array}$ & South & $\begin{array}{l}\text { South } \\
\text { West }\end{array}$ & $\begin{array}{l}\text { North West/ } \\
\text { Plateau }\end{array}$ \\
\hline $\begin{array}{l}\text { Single cropping } \\
\text { Limited double } \\
\text { Double cropping } \\
\text { Double with rice } \\
\text { Double rice } \\
\text { Triple cropping } \\
\text { Triple rice } \\
\text { Total }\end{array}$ & $\begin{array}{r}94 \\
111 \\
287 \\
. . \\
. . \\
. \\
49 .\end{array}$ & $\begin{array}{r}138 \\
21 \\
. . \\
. . \\
. . \\
. . \\
. . \\
159\end{array}$ & $\begin{array}{r}. . \\
7 \ddot{3} \\
115 \\
41 \\
. . \\
229\end{array}$ & $\begin{array}{r}10 \\
14 \\
171 \\
62 \\
. . \\
257\end{array}$ & $\begin{array}{r}. . . \\
. . \\
18 \\
39 \\
116 \\
78 \\
251\end{array}$ & $\begin{array}{r}62 \\
64 \\
102 \\
90 \\
66 \\
. . \\
384\end{array}$ & $\begin{array}{r}200 \\
48 \\
22 \\
. . \\
. . \\
. . \\
270\end{array}$ \\
\hline
\end{tabular}




\section{Towards estimating agricultural production relations for China}

crop in total revenue and the number of counties where the crop is grown. The patterns clearly differ across regions. Rice, maize and wheat contribute most to revenue. However, fruit and vegetables are also important products in most regions.

Table 8.2 does not capture the broad variation of over 400 crop combinations, which enter the model through the crop (-mix) variables $M_{m}$. This definition is listed in Table 8.3. Guiding principles in the definition of crop-mix variables were: not to exceed a total of four crop-mix parameters, and to give missing major crops priority over the less important ones. Each county has, at most, one non-zero crop-mix dummy. Table 8.4 presents the results of these cropmix definitions.

\section{Data checking}

Multiple checks were conducted in order to improve data reliability and consistency. This was done on the basis of checking various relative indicators such as the irrigation ratio, land per labourer, land per capita, output per sown hectare and each non-land input per hectare and per labourer. Occasionally, errors in the original publications could be corrected by comparison between data sources. In some cases missing or dubious data could be corrected by reference to data for other years. When data was missing or appeared to be highly implausible but could not be corrected by using other sources, the respective county was dropped from the estimation.

Eventually, of the total 2,378 administrative units contained in the LUC database, 2,042 counties could be retained in the study. That is, data were complete and were judged sufficiently reliable to be used for the output side as well as the input side of the estimation. Table 8.5 gives an account by region. Incomplete county level records eliminated 322 counties, and outliers mainly for labour and machinery figures eliminated another 14 . These outliers were concentrated in the North, Plateau and North East regions. Only 20 counties on the Plateau located in Qinghai province qualified for inclusion in the estimation. Xizang (Tibet) had no acceptable data records at all. Consequently, it was decided to pool Qinghai with the North West region based on the similarity of the cropping zone pattern.

\section{Results from estimation}

Parameters of the model were estimated by Nonlinear Least Squares (NLS) separately for each region. The North West region and Plateau (a few counties in Qinghai province) were treated jointly because the number of valid 


\section{Dilemmas of China's Growth in the Twenty-First Century}

\section{Figure 8.2}

Annual potential production weighted average of irrigation and rain-fed potentials (tonnes/ha)

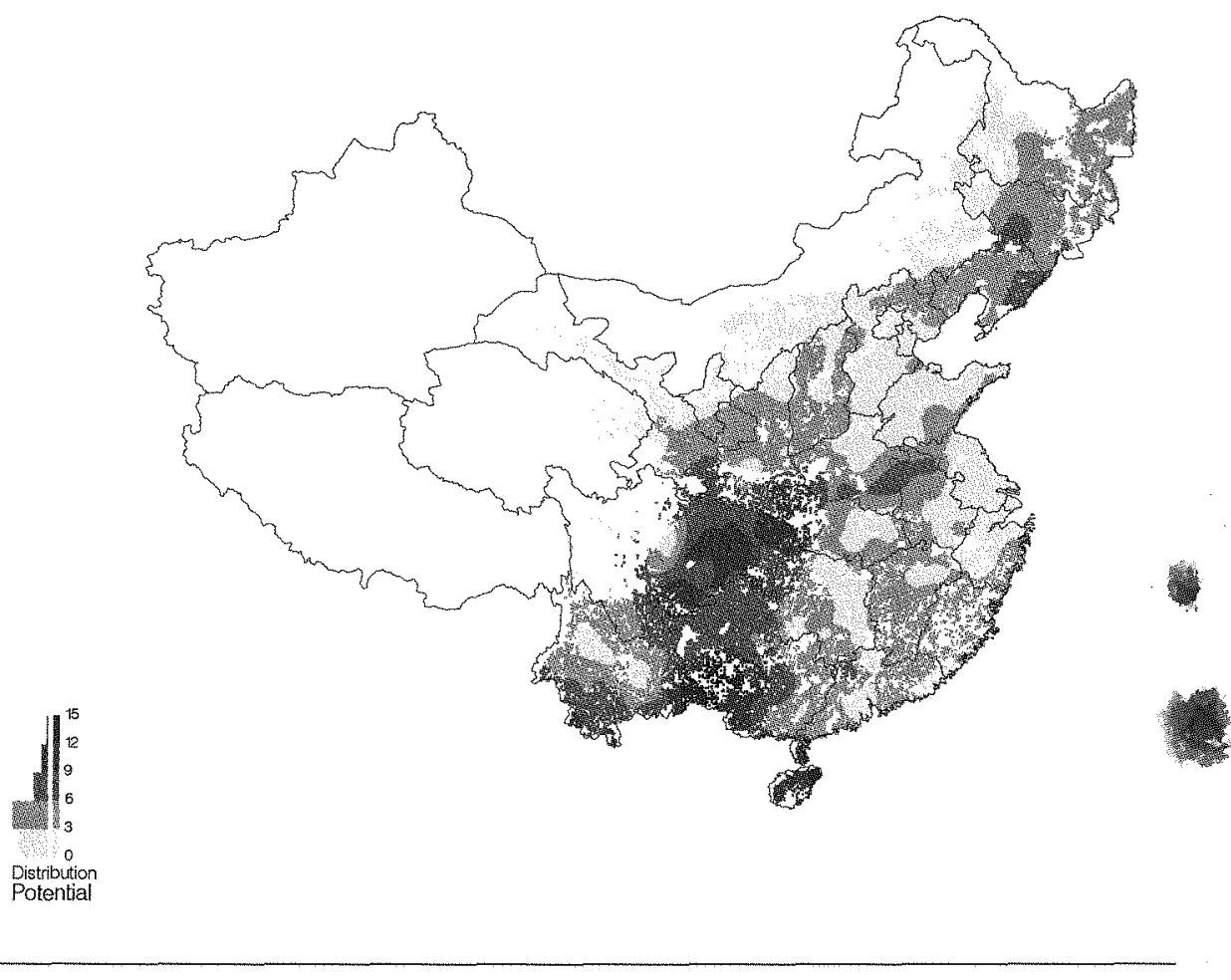

observations (20) was too low for a separate estimation of the Plateau region. The presentation of results proceeds as follows. We check whether the error term meets the statistical requirements, which permit us to consider NLS as a maximum likelihood estimator. Next, we discuss the estimation results of the input response function $\mathrm{G}$. Coefficient values of the output index $\mathrm{Q}$ are then reported. Finally, we present and discuss the spatial distribution of calculated implicit (shadow) prices, and of the marginal productivity of input factors.

\section{Analysis of error term}

To test whether NLS amounts to maximum likelihood estimation, we check normality, homoscedasticity and independence of the error term. We apply two tests, one parametric and one non-parametric. First, we use the common Shapiro-Wilk test (Shapiro and Wilk 1965) to check whether for the sample 
Towards estimating agricultural production relations for China

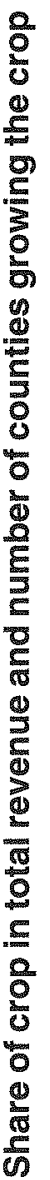

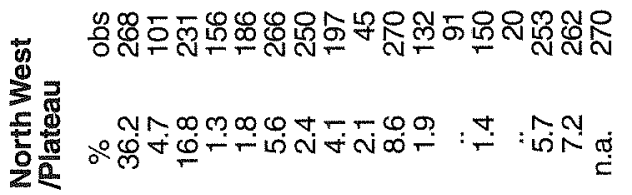

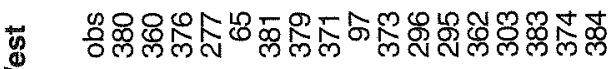

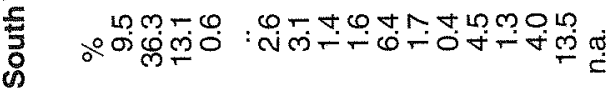

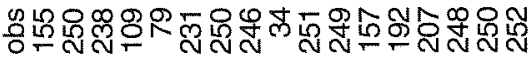

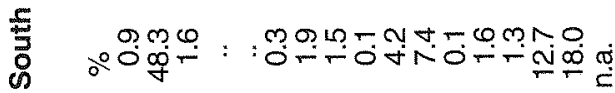

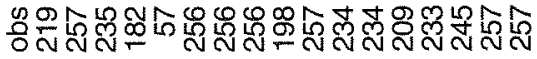

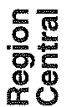

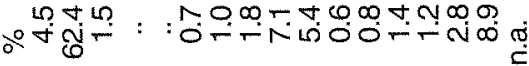

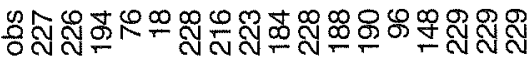

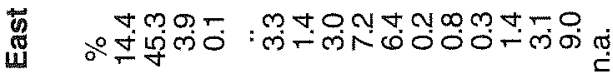

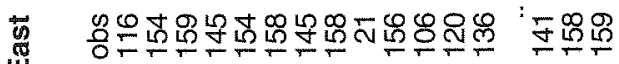

$\frac{5}{2}$

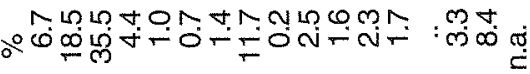

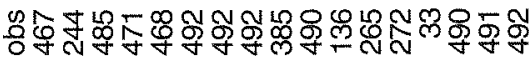

돈

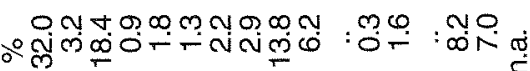

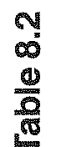

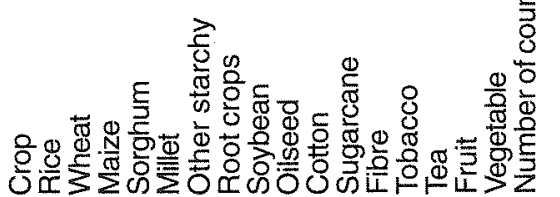




\section{Dilemmas of China's Growth in the Twenty-First Century}

Table 8.3 Definition of crop-mix variables $M_{m}$ (entries are crops missing)

\begin{tabular}{|c|c|c|c|c|c|}
\hline & Mix 1 & Mix 2 & $\operatorname{Mix} 3$ & Mix 4 & No mix \\
\hline North & Wheat & Maize, cotton, fruit & $\geq 3$ smaller crops & .. & All other cases \\
\hline North East & $\begin{array}{l}\text { Maize, rice, } \\
\text { soybean, } \\
\text { vegetables }\end{array}$ & Wheat & $\geq 3$ smaller crops & .. & All other cases \\
\hline East & Rice, wheat & $\geq 5$ smaller crops & .. & .. & All other cases \\
\hline Central & $\begin{array}{l}\text { Rice, } \\
\text { vegetables, } \\
\text { cotton }\end{array}$ & $\geq 3$ smaller crops & .. &.. & All other cases \\
\hline South & $\begin{array}{l}\text { Rice, fruit, } \\
\text { vegetables, } \\
\text { sugarcane }\end{array}$ & $\geq 3$ smaller crops & .. & .. & All other cases \\
\hline South West & $\begin{array}{l}1 \text { of rice, } \\
\text { vegetables, } \\
\text { maize/wheat }\end{array}$ & $\begin{array}{l}2 \text { or } 3 \text { of Wheat } \\
\text { Rice, vegetables, } \\
\text { maize }\end{array}$ & .. & .. & All other cases \\
\hline North West & $\begin{array}{l}1 \text { of wheat, } \\
\text { maize, fruit, } \\
\text { vegetables }\end{array}$ & $\begin{array}{l}2 \text { or } 3 \text { of wheat, } \\
\text { maize, fruit, } \\
\text { vegetables }\end{array}$ & $\begin{array}{l}4 \text { or } 5 \text { smaller } \\
\text { crops }\end{array}$ & $\begin{array}{l}\geq 6 \\
\text { smaller } \\
\text { crops }\end{array}$ & All other cases \\
\hline
\end{tabular}

Table 8.4 County number corresponding to the crop-mix variables by region

\begin{tabular}{lrrrrrrr}
\hline & North & $\begin{array}{l}\text { North } \\
\text { East }\end{array}$ & East & $\begin{array}{l}\text { Region } \\
\text { Central }\end{array}$ & South & $\begin{array}{l}\text { South } \\
\text { West }\end{array}$ & $\begin{array}{l}\text { North West } \\
\text { Plateau }\end{array}$ \\
None & 130 & 88 & 200 & 159 & 123 & 163 & 87 \\
Mix 1 & 25 & 7 & 5 & 59 & 7 & 14 & 36 \\
Mix 2 & 87 & 42 & 25 & 39 & 121 & 13 & 8 \\
Mix 3 & 250 & 22 &.. &.. &.. & 194 & 101 \\
Mix 4 &.. &.. &.. &.. &.. &.. & 38 \\
Total & 492 & 159 & 229 & 257 & 251 & 384 & 270 \\
\hline
\end{tabular}

\section{Table 8.5 Observations per region}

\begin{tabular}{lrrrrrrrr}
\hline & North & $\begin{array}{c}\text { North } \\
\text { East }\end{array}$ & East & \multicolumn{2}{c}{$\begin{array}{c}\text { Region } \\
\text { Central South }\end{array}$} & $\begin{array}{l}\text { South North West } \\
\text { West }\end{array}$ & Total \\
All counties & 510 & 184 & 244 & 275 & 272 & 402 & 491 & 2378 \\
$\begin{array}{l}\text { Missing data } \\
\text { Outliers }\end{array}$ & 13 & 25 & 15 & 18 & 21 & 18 & 212 & 322 \\
$\begin{array}{l}\text { (Labour, machinery) } \\
\text { For estimation }\end{array}$ & 5 & 0 & 0 & 0 & 0 & 0 & 9 & 14 \\
\hline
\end{tabular}




\section{Towards estimating agricultural production relations for China}

as a whole, the errors are a random sample from the normal distribution. Second, we check whether errors might be spatially correlated, albeit locally. This is done by applying a spatial non-parametric (kernel density) regression (Bierens 1987; Keyzer and Sonneveld 1997), regressing the error term on longitude and latitude of the counties. For each county, the estimated value is calculated and the derivative with respect to longitude and latitude and the estimated probability of wrong sign for that derivative are calculated. Lack of spatial correlation finds expression in frequently changing signs of the derivatives and in a high average probability of the wrong sign of derivatives.

Table 8.6 presents the Shapiro-Wilk statistic. The normality test is passed at the 5 per cent level for all regions. The table also shows results from kernel density regression and indicates that no spatial dependency could be detected anywhere. On average, the probability of a wrong sign of the derivative in either direction is close enough to 0.5 , implying that the error term could vary in any direction. Therefore, there is no need to correct for the spatial correlation of errors in the regression, and homoscedasticity and independence can be assumed.

We conclude that the model can be estimated by least squares. Appendix 8.1 describes an iterative numerical procedure to perform this estimation.

\section{Input response}

Next, we report on the coefficient values and their likelihood ratios, and on the elasticities of the input response equations, recalling that these were actually estimated simultaneously with the output mix equations. The likelihood ratio is used to check the robustness of the coefficients.

First, let us briefly recapitulate its main principles (see Gallant 1987; Davidson and MacKinnon 1993). We denote model parameters by $\zeta_{1}, \zeta_{2}$. Under our null hypothesis, $H_{0}: \zeta_{1}=\bar{\zeta}_{1}$ and $\zeta_{2}$ unrestricted, while under the alternative $H_{1}$ : both $\zeta_{1}$ and $\zeta_{2}$ are unrestricted. With maximum likelihood estimation, the significance level of an estimated parameter $\zeta_{1}$ can be determined by an $F$-test:

$$
\mathrm{F}(\mathrm{j}, \mathrm{n}-\mathrm{m})=\left(\frac{S\left(\bar{\zeta}_{1}, \tilde{\zeta}_{2}\right)}{S\left(\hat{\zeta}_{1}, \hat{\zeta}_{2}\right)}-1\right) \cdot \frac{n-m}{j}
$$

where $n, m$ and $j$ are the number of observations, parameters and restrictions, respectively; $S\left(\hat{\zeta}_{1}, \hat{\zeta}_{2}\right)$ is the minimum residual sum of squares corresponding to maximisation of the unrestricted likelihood function. $S\left(\bar{\zeta}_{1}, \widetilde{\zeta}_{2}\right)$ is the residual sum of squares for given reference value $\bar{\zeta}_{1}$ and free $\widetilde{\zeta}_{2}$, corresponding to maximisation of the restricted likelihood function. Critical value for the region with smallest sample size (that is the North East region) $F(1,159)$ at 0.95 is 3.83 . 


\section{Dilemmas of China's Growth in the Twenty-First Century}

\begin{tabular}{|c|c|c|c|c|c|c|c|}
\hline Table 8.6 & sts on & he erro & r term & & & & \\
\hline Coefficient & North & $\begin{array}{l}\text { North } \\
\text { East }\end{array}$ & East & $\begin{array}{l}\text { Region } \\
\text { Central }\end{array}$ & South & $\begin{array}{l}\text { South } \\
\text { West }\end{array}$ & $\begin{array}{l}\text { North West/ } \\
\text { Plateau }\end{array}$ \\
\hline Shapiro-Wilk's W & 0.989 & 0.977 & 0.986 & 0.982 & 0.980 & 0.988 & 0.983 \\
\hline Probability $<W$ & 0.876 & 0.231 & 0.726 & 0.416 & 0.234 & 0.820 & 0.453 \\
\hline \multicolumn{8}{|c|}{$\begin{array}{l}\text { Spatial dependency using the mollifier method: } \\
\text { Probability of wrong sign of derivative: }\end{array}$} \\
\hline Longitude & 0.454 & 0.443 & 0.454 & 0.461 & 0.458 & 0.465 & 0.446 \\
\hline Latitude & 0.441 & 0.418 & 0.455 & 0.457 & 0.452 & 0.448 & 0.423 \\
\hline
\end{tabular}

As a reference value we use 50 per cent of the original estimate $\hat{\zeta}_{1}$, as opposed to the usual reference value zero because the function form is given and all variables have to enter the welfare model eventually. ${ }^{12}$ Hence, we need to assess the robustness of the estimated parameter value, rather than deciding whether the variable should be included at all.

\section{Coefficients}

Table 8.7 presents the estimated coefficients of the input response function index $G$, their corresponding likelihood ratios and the number of observations in each region. Clearly, for parameters with zero value no likelihood ratio can be calculated. Since $\sum_{j} \theta_{j}=1$ no LR for $\theta_{\text {Nurrient }}$ is estimated. As the parameter $\delta_{\text {Rainfed }}$ is by definition equal to unity it has no LR value.

The area index $\mathrm{H}(\mathrm{A})$ is preset before estimation. The parameter $\delta_{\text {Irrigated }}$ converts irrigated land into rainfed equivalent. It is chosen on the interval between unity and the ratio of potential yield on irrigated land to potential yield on rainfed land and its significance was assessed. The estimation results for the North East region are generally slightly deviant on the input side. The quality of the input data and potential production in the North East is probably causing this result. Except for $\beta_{\text {Nutrient }}$ in the North East all parameters are significant at the 95 per cent level.

Not surprisingly, the input specific parameters $\gamma$ show a large range of variability across regions, justifying estimation by region as opposed to a pooled estimation for China as a whole. For the Northern regions, including the North West/Plateau, North and North East, fertiliser substitution is at the lower bound and relatively inelastic (elasticity of substitution $\mathcal{E}_{\text {Nurrient }}=3.33$ ). Generally, the constants b of the input groups are small or zero. The upper bound for $\rho_{\text {Power }}$ of -0.25 is in effect for five regions. The substitution elasticities 


\section{Towards estimating agricultural production relations for China}

for the power-related inputs range from 0.38 in the South West to 0.80 in most other regions.

\section{Elasticities and marginal values}

As a further description of the results from estimation, we present the output elasticities by input category, evaluated at the regional mean (Table 8.8) (see Appendix 8.3 for a specification of the analytical form of elasticities). Since the input response function $G$ is linear homogeneous of degree one in $(V, A)$, the elasticities of the inputs add to unity.

The results suggest a differentiation into three zones. First, the Southeast part of China, which includes the East, Central, South and to some extend South West regions, show a great similarity in elasticities for most inputs and input groups (Power, Nutrient and Land). The elasticity is highest for chemical fertiliser, followed by machinery and irrigated land, while labour has a small contribution to the output index. Second, we identify the North and North West/Plateau regions where the similarity between the elasticities manifests mainly in their pattern with respect to the non-land inputs and not so much in their levels. The levels of elasticities in the North region are comparable to the first zone. The picture is different in the remaining region, the North East, which has the highest elasticity for labour.

The elasticities of land-use types might wrongly convey the impression that investment in irrigation in the North East, South West and North West/ Plateau is unprofitable. In fact the lower elasticities for irrigated land in some regions merely reflects the lower area under irrigation (see Appendix 8.2). For example, in the North East region rainfed agriculture is the dominant landuse type (78 per cent) and $\delta_{\text {Irrigated }}$ is 1.59 , resulting in a ratio of rainfed over irrigated land of about 2.9. To assess the relative productivity of investment in irrigated and non-irrigated, a common area basis is needed. The two lines at the bottom of Table 8.8 measure the percentage increase in output if the land basis expands by 1 per cent of irrigated and non-irrigated land, respectively. Since $\delta_{\text {Irrigared }}$ exceeds $\delta_{\text {Rainfed }}$ irrigation appears to be more productive.

Figures 8.3 and 8.4 map the county level elasticities for labour and machinery and seem to confirm the spatial pattern of the regional averages. The maps are computed on the basis of kernel density regression as in Keyzer and Sonneveld (1997). The histogram on the left of each panel shows the percentage shares of the coloured areas. A combined mask of estimated counties and agricultural areas as given by Figure 8.1 is applied.

As a further characterisation of the differences across regions, we calculate the marginal values (Table 8.9). These reflect the variability of implicit wages, 


\section{Table 8.7 Estimated coefficients for the input response function}

\begin{tabular}{|c|c|c|c|c|c|c|c|}
\hline Coefficient & North & $\begin{array}{l}\text { North } \\
\text { East }\end{array}$ & East & $\begin{array}{l}\text { Region } \\
\text { Central }\end{array}$ & South & $\begin{array}{l}\text { South } \\
\text { West }\end{array}$ & $\begin{array}{l}\text { North West/ } \\
\text { Plateau }\end{array}$ \\
\hline$\zeta_{\text {Single cropping }}$ & $\begin{array}{l}0.939 \\
33.8\end{array}$ & $\begin{array}{l}182.131 \\
136.6\end{array}$ & $\ddot{n}$.a. & $\ddot{n} . a$. & $\ddot{\text { n.a. }}$ & $\begin{array}{l}3.050 \\
258.0\end{array}$ & $\begin{array}{l}40.205 \\
129.3\end{array}$ \\
\hline$\zeta_{\text {Limited double }}$ & $\begin{array}{l}0.892 \\
41.8\end{array}$ & $\begin{array}{l}169.202 \\
75.0\end{array}$ & $\ddot{9} 2.5$ & $\begin{array}{l}5.150 \\
\text { n.a. }\end{array}$ & n.a. & $\begin{array}{l}2.217 \\
208.2\end{array}$ & $\begin{array}{l}32.751 \\
151.3\end{array}$ \\
\hline$\zeta_{\text {Double cropping }}$ & $\begin{array}{l}0.841 \\
43.6\end{array}$ & $\ddot{n}$.a. & $\begin{array}{l}5.983 \\
711.4\end{array}$ & $\begin{array}{l}4.353 \\
159.9\end{array}$ & $\ddot{n} . a$. & $\begin{array}{l}2.111 \\
275.5\end{array}$ & $\begin{array}{l}33.862 \\
154.9\end{array}$ \\
\hline$\zeta_{\text {Double with rice }}$ & $\ddot{\text { n.a. }}$ & n.a. & $\begin{array}{l}5.768 \\
793.6\end{array}$ & $\begin{array}{l}3.502 \\
595.0\end{array}$ & $\begin{array}{l}2.806 \\
111.8\end{array}$ & $\begin{array}{l}1.891 \\
32.8\end{array}$ & $\ddot{n} . a$. \\
\hline$\zeta_{\text {Double rice }}$ & $\ddot{n} . a$. & n.a. & $\begin{array}{l}5.169 \\
636.0\end{array}$ & $\begin{array}{l}2.887 \\
2077.7\end{array}$ & $\begin{array}{l}2.553 \\
178.8\end{array}$ & $\begin{array}{l}1.742 \\
62.9\end{array}$ & $\ddot{n} . a$. \\
\hline$\zeta_{\text {Triple cropping }}$ & $\ddot{n}$. a. & $\ddot{n}$.a. & n.... & $\ddot{\text { n.a. }}$ & $\begin{array}{l}2.365 \\
30.5\end{array}$ & n.... & n... \\
\hline$\zeta_{\text {Triple rice }}$ & n... & $\ddot{n}$.a. & n... & $\ddot{n}$.a. & $\begin{array}{l}2.595 \\
78.7\end{array}$ & n.a. & n... \\
\hline$\theta_{\text {Power }}$ & $\begin{array}{l}0.320 \\
376.6\end{array}$ & $\begin{array}{l}0.700^{*} \\
772.9\end{array}$ & $\begin{array}{l}0.430 \\
4.8\end{array}$ & $\begin{array}{l}0.365 \\
115.4\end{array}$ & $\begin{array}{l}0.341 \\
160.2\end{array}$ & $\begin{array}{l}0.300^{*} \\
210.7\end{array}$ & $\begin{array}{l}0.555 \\
22.7\end{array}$ \\
\hline$\theta_{\text {Nutrient }}$ & 0.680 & 0.300 & 0.570 & 0.635 & 0.659 & 0.700 & 0.445 \\
\hline$\beta_{\text {Power }}$ & n.a. & n.a. & $\begin{array}{l}0.013 \\
20.8\end{array}$ & $\begin{array}{l}0.001 \\
68.7\end{array}$ & $\begin{array}{l}0.005 \\
122.7\end{array}$ & $\begin{array}{l}0.006 \\
33.9\end{array}$ & $\begin{array}{l}0.001 \\
16.8\end{array}$ \\
\hline$\beta_{\text {Nutrient }}$ & $\bar{n}$ n.a. & $\begin{array}{l}0.031 \\
2.8\end{array}$ & $\begin{array}{l}0.005 \\
96.6\end{array}$ & n.a. & n.a. & $\begin{array}{l}0.013 \\
15.4\end{array}$ & $\begin{array}{l}0.003 \\
10.6\end{array}$ \\
\hline$\rho_{\text {Power }}$ & $\begin{array}{l}-0.250^{*} \\
43.4\end{array}$ & $\begin{array}{l}-0.250^{*} \\
126.1\end{array}$ & $\begin{array}{l}-0.250^{*} \\
15.5\end{array}$ & $\begin{array}{l}-0.250^{\star} \\
20.4\end{array}$ & $\begin{array}{l}-0.250^{*} \\
24.1\end{array}$ & $\begin{array}{l}-1.630 \\
74.6\end{array}$ & $\begin{array}{l}-1.265 \\
48.9\end{array}$ \\
\hline$\rho_{\text {Nutrient }}$ & $\begin{array}{l}0.700^{*} \\
30.8\end{array}$ & $\begin{array}{l}0.700^{\star} \\
17773.5\end{array}$ & $\begin{array}{l}1.000^{\star} \\
16.8\end{array}$ & $\begin{array}{l}1.000^{\star} \\
3552.1\end{array}$ & $\begin{array}{l}1.000^{*} \\
243.1\end{array}$ & $\begin{array}{l}1.000^{*} \\
255.3\end{array}$ & $\begin{array}{l}0.700^{*} \\
3.2\end{array}$ \\
\hline$\gamma_{\text {Labour }}$ & $\begin{array}{l}0.161 \\
30.0\end{array}$ & $\begin{array}{l}2.062 \\
14.5\end{array}$ & $\begin{array}{l}0.464 \\
15.7\end{array}$ & $\begin{array}{l}0.389 \\
50.2\end{array}$ & $\begin{array}{l}0.291 \\
40.9\end{array}$ & $\begin{array}{l}3.010 \\
22.5\end{array}$ & $\begin{array}{l}7.856 \\
16.6\end{array}$ \\
\hline$\gamma_{\text {Machine }}$ & $\begin{array}{l}0.807 \\
446.5\end{array}$ & $\begin{array}{l}2.141 \\
12.1\end{array}$ & $\begin{array}{l}1.024 \\
153.5\end{array}$ & $\begin{array}{l}1.779 \\
2264.7\end{array}$ & $\begin{array}{l}1.457 \\
817.3\end{array}$ & $\begin{array}{l}3.179 \\
34.9\end{array}$ & $\begin{array}{l}23.589 \\
22.6\end{array}$ \\
\hline$\gamma_{\text {Chemicais }}$ & $\begin{array}{l}3.235 \\
38.0\end{array}$ & $\begin{array}{l}0.337 \\
10.8\end{array}$ & $\begin{array}{l}0.160 \\
549.5\end{array}$ & $\begin{array}{l}1.578 \\
826.3\end{array}$ & $\begin{array}{l}0.728 \\
174.4\end{array}$ & $\begin{array}{l}0.934 \\
12.8\end{array}$ & $\begin{array}{l}0.120 \\
12.5\end{array}$ \\
\hline$\gamma_{\text {Organic }}$ & $\begin{array}{l}1.481 \\
37.8\end{array}$ & $\begin{array}{l}0.025 \\
11.2\end{array}$ & $\begin{array}{l}0.135 \\
97.3\end{array}$ & $\begin{array}{l}0.770 \\
75.5\end{array}$ & $\begin{array}{l}0.623 \\
28.3\end{array}$ & $\begin{array}{l}0.387 \\
37.8\end{array}$ & $\begin{array}{l}0.029 \\
13.8\end{array}$ \\
\hline$\delta_{\text {Irigated }}{ }^{1}$ & $\begin{array}{l}2.110 \\
35.5\end{array}$ & $\begin{array}{l}1.590 \\
4.9\end{array}$ & $\begin{array}{l}1.000 \\
117.2\end{array}$ & $\begin{array}{l}1.000 \\
54.4\end{array}$ & $\begin{array}{l}1.000 \\
28.7\end{array}$ & $\begin{array}{l}1.000 \\
30.6\end{array}$ & $\begin{array}{l}2.210 \\
22.2\end{array}$ \\
\hline$\delta_{\text {Rainted }}{ }^{1}$ & 1.000 & 1.000 & 1.000 & 1.000 & 1.000 & 1.000 & 1.000 \\
\hline Observations & 492 & 159 & 229 & 257 & 173 & 384 & 270 \\
\hline
\end{tabular}

Notes: "parameter at bound; preset value 4.9. Figures in italics are likelihood ratios. 


\section{Towards estimating agricultural production relations for China}

rental cost of machinery and price of chemical and organic fertilisers.

The marginal value of labour is high in the Northern regions and, as could be expected, low in densely populated areas of the Central and South regions where marginal returns to land are relatively high for both irrigated and rainfed land. Despite its dense population, the East region reflects - with the relatively high marginal value of labour-the attractiveness of the more industrialised area.

\section{Output index}

The coefficients of the output index function $Q$ appear in Table 8.10. For the major staple crops (rice, wheat and maize) they generally come out very similarly across regions. Deviations are mainly due to the fact that certain crops are sometimes a major crop in one region but a minor crop in another. Wheat and maize are outliers in opposite directions in the South, where they contribute less than 1.0 and 1.6 per cent to total crop revenue, respectively. Wheat can only be grown in a few scattered areas in Fujian and Guangdong. The variation in estimates is most pronounced for the minor crops but estimates are stable for vegetables and (to a lesser extent) fruits, which are present in almost all counties and baskets of various kinds. The crop-mix correction factors $\mathrm{m}_{\mathrm{m}}$ vary across regions and crop mixes. Most are negative as expected, especially those associated with a major crop. Other crop-mix parameters can be positive since some of the regional minor crops are a major crop at county level. The significance level for most parameters is well above 95 per cent.

\section{Implicit prices}

We are now ready to calculate implicit prices and compare these with the consumer prices in nearby urban centres. The difference between them measures an implicit trade and transportation margin. Clearly, this margin should increase with the distance to the main consuming areas. We show results for rice and wheat, the major staples, by means of a price map computed through kernel density regression.

Figure 8.5 displays the implicit price of rice for the main rice-producing provinces. Figure 8.6 shows the population density in 100 persons per $\mathrm{km}^{2}$. It appears that the farm gate price of rice is in general higher in areas with a high population density. This holds especially for the relatively urbanised areas in the Southern provinces of Guandong, Guangxi and Hainan. The Red Basin area in Sichuan and the Dongbei Pingyuan Plains stretching from south to north in the three northeastern provinces also exhibit rising prices closer to consuming areas. Thus, the figures indicate that our (purely quantity-based) estimation results in a positive trade and transportation margin.

The implicit prices of the two other major crops, wheat and maize, for the relevant producing areas are shown in Figures 8.7 and 8.8, respectively. They 


\section{Dilemmas of China's Growth in the Twenty-First Century}

\section{Figure 8.3 Elasticity for labour}

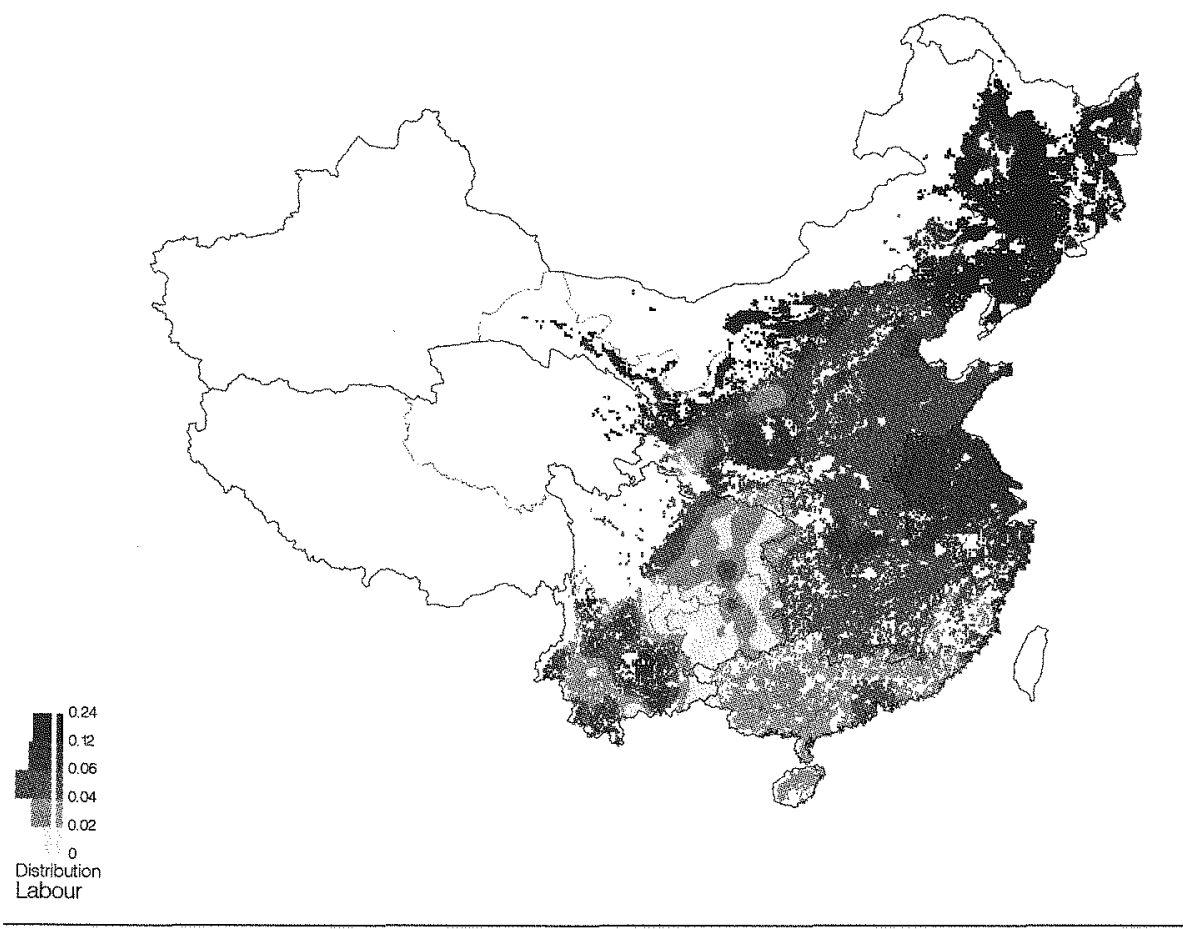

also show that prices are rising as one nears densely populated areas. Wheat has an outlier in the South region, resulting in a high farm gate price. Note that there is no wheat in the plains of the North East where conditions are more favourable for maize, which is grown on more than 50 per cent of the area.

Table 8.11 compares observed farm gate prices and implicit prices at the regional level for rice, wheat and maize. The implicit prices are weighted with the county production. In the main producing regions, they are seen to fluctuate around the farm gate levels in the original statistics. As mentioned earlier, these recorded farm gate prices are a quantity-weighted mean of quota prices, negotiated prices and free market prices. They tend to lie below marginal productivity and hence below implicit free market prices.

We conclude that the differences between the observed market prices and the imputed farm gate prices leave positive margins that follow a plausible geographical pattern. This suggests that by keeping these margins exogenous to the farm model in a county, it becomes possible to reproduce the main properties of crop farming in China by means of a static profit maximising model. 


\section{Figure 8.4 Elasticity for machinery}

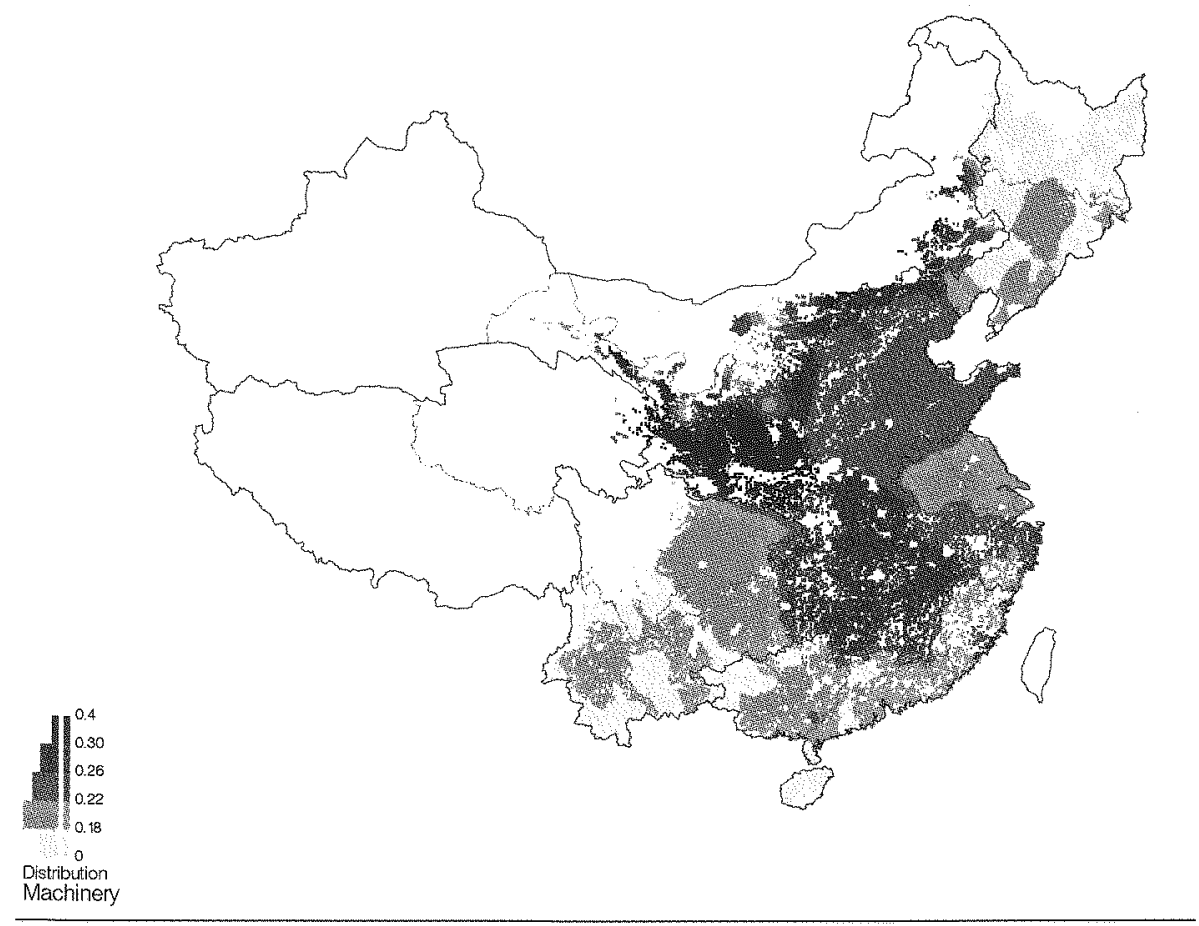

\section{Table 8.8}

\section{Output elasticities of land and non-land inputs at the regional mean}

\begin{tabular}{|c|c|c|c|c|c|c|c|}
\hline Input & North & $\begin{array}{l}\text { North } \\
\text { East }\end{array}$ & East & $\begin{array}{l}\text { Region } \\
\text { Central }\end{array}$ & South & $\begin{array}{l}\text { South } \\
\text { West }\end{array}$ & $\begin{array}{l}\text { North West } \\
\text { Plateau }\end{array}$ \\
\hline $\begin{array}{l}\text { Labour } \\
\text { Machinery } \\
\text { Power } \\
\text { Chemical } \\
\text { fertiliser }\end{array}$ & $\begin{array}{l}0.052 \\
0.248 \\
0.300 \\
0.309\end{array}$ & $\begin{array}{l}0.172 \\
0.160 \\
0.332 \\
0.122\end{array}$ & $\begin{array}{l}0.095 \\
0.216 \\
0.311 \\
0.392\end{array}$ & $\begin{array}{l}0.054 \\
0.279 \\
0.333 \\
0.344\end{array}$ & $\begin{array}{l}0.036 \\
0.202 \\
0.238 \\
0.376\end{array}$ & $\begin{array}{l}0.028 \\
0.211 \\
0.239 \\
0.398\end{array}$ & $\begin{array}{l}0.100 \\
0.331 \\
0.431 \\
0.209\end{array}$ \\
\hline $\begin{array}{l}\text { Organic } \\
\text { fertiliser }\end{array}$ & 0.084 & 0.005 & 0.121 & 0.102 & 0.184 & 0.192 & 0.042 \\
\hline $\begin{array}{l}\text { Nutrient } \\
\text { Irrigated area } \\
\text { Rainfed area } \\
\text { Land }\end{array}$ & $\begin{array}{l}0.393 \\
0.215 \\
0.092 \\
0.307\end{array}$ & $\begin{array}{l}0.127 \\
0.140 \\
0.401 \\
0.541\end{array}$ & $\begin{array}{l}0.513 \\
0.131 \\
0.045 \\
0.176\end{array}$ & $\begin{array}{l}0.446 \\
0.165 \\
0.056 \\
0.221\end{array}$ & $\begin{array}{l}0.560 \\
0.127 \\
0.075 \\
0.202\end{array}$ & $\begin{array}{l}0.590 \\
0.063 \\
0.108 \\
0.171\end{array}$ & $\begin{array}{l}0.251 \\
0.138 \\
0.180 \\
0.318\end{array}$ \\
\hline \multicolumn{8}{|c|}{ Elasticity of land-index $\mathrm{H}$ if change is attributed to: } \\
\hline $\begin{array}{l}\text { Irrigated area } \\
\text { Rainfed area }\end{array}$ & $\begin{array}{l}0.414 \\
0.196\end{array}$ & $\begin{array}{l}0.779 \\
0.490\end{array}$ & $\begin{array}{l}0.185 \\
0.185\end{array}$ & $\begin{array}{l}0.221 \\
0.221\end{array}$ & $\begin{array}{l}0.203 \\
0.203\end{array}$ & $\begin{array}{l}0.171 \\
0.171\end{array}$ & $\begin{array}{l}0.544 \\
0.246\end{array}$ \\
\hline
\end{tabular}




\section{Dilemmas of China's Growth in the Twenty-First Century}

\begin{tabular}{|c|c|c|c|c|c|c|c|}
\hline \multirow{2}{*}{$\begin{array}{l}\text { Table } 8.9 \\
\\
\text { Derivative } \\
\partial \mathrm{G} / \partial \mathrm{V}\end{array}$} & \multicolumn{5}{|c|}{ Marginal values at the mean (yuan) } & \multirow[b]{2}{*}{$\begin{array}{l}\text { South i } \\
\text { West }\end{array}$} & \multirow[b]{2}{*}{$\begin{array}{l}\text { North West/ } \\
\text { Plateau }\end{array}$} \\
\hline & North & $\begin{array}{l}\text { North } \\
\text { East }\end{array}$ & East & $\begin{array}{l}\text { Region } \\
\text { Central }\end{array}$ & South & & \\
\hline $\begin{array}{l}\text { Labour } \\
\text { (person) }\end{array}$ & 113.90 & 580.05 & 242.11 & 125.62 & 88.83 & 41.63 & 160.20 \\
\hline $\begin{array}{l}\text { Machinery } \\
(\mathrm{kW})\end{array}$ & 429.76 & 348.17 & 614.77 & 1086.19 & 784.91 & 1056.26 & 573.56 \\
\hline $\begin{array}{l}\text { Chemical } \\
\text { fertiliser (kg) }\end{array}$ & 4.72 & 1.61 & 5.76 & 6.20 & 5.62 & 8.23 & 2.96 \\
\hline $\begin{array}{l}\text { Organic } \\
\text { fertiliser }(\mathrm{kg})\end{array}$ & 2.70 & 0.16 & 4.83 & 3.03 & 4.81 & 3.41 & 0.77 \\
\hline$\partial G / \partial A$ & & & & & & & \\
\hline $\begin{array}{l}\text { Irrigated area } \\
\text { farmland (ha) }\end{array}$ & 1329.98 & 1190.84 & 862.63 & 1296.18 & 871.70 & 490.13 & 539.93 \\
\hline $\begin{array}{l}\text { Rainfed area } \\
\text { farmland (ha) }\end{array}$ & 630.32 & 748.95 & 862.63 & 1296.18 & 871.70 & 490.13 & 244.31 \\
\hline
\end{tabular}

\section{Marginal productivity}

Figures 8.9 and 8.10 present maps for the marginal productivity of labour and machinery. It appears that the marginal productivity of agricultural labour is usually higher in the neighbourhood of large urban areas: Hong Kong, Shanghai, Beijing, Tiajin and the delta of Liaoning. The figures also show that in the Southern regions (South West, Central and South) the marginal productivity is higher for machinery and lower for labour.

Figure 8.11 maps the marginal value of irrigated land, which by construction stands in fixed, region-specific proportion to the marginal productivity of rainfed land. Along the coastal zone and in the North East region, it follows the pattern of population density quite closely but inland the relationship is loose. Although marginal productivity is somewhat higher in the Red Basin area in Sichuan than in the surrounding mountainous area, its level lies substantially below comparable urban areas along the coast.

At the regional level, the average implicit costs (and returns) per labourer for land and wage are lowest in the Central and South West (Table 8.12). In the South West region, in 1990 an average labourer earned an income of 287 yuan. For the coastal regions South, East and North, the earnings for a crop labourer range between 631-813 yuan on average. This pattern is in line with the observed out-migration to the coastal provinces during the last decade. The marginal productivities of labour and land are highest in the northern provinces. 
Towards estimating agricultural production relations for China

Table 8.10 Estimated coefficients for the output function

\begin{tabular}{|c|c|c|c|c|c|c|c|}
\hline Coefficient & North & $\begin{array}{l}\text { North } \\
\text { East }\end{array}$ & East & $\begin{array}{l}\text { Region } \\
\text { Central }\end{array}$ & South & $\begin{array}{l}\text { South } \\
\text { West }\end{array}$ & $\begin{array}{l}\text { North West } \\
\text { Plateau }\end{array}$ \\
\hline$\alpha_{0}{ }^{1}$ & $\begin{array}{l}1.500 \\
46.6\end{array}$ & $\begin{array}{l}1.500 \\
25.4\end{array}$ & $\begin{array}{l}1.500 \\
29.9\end{array}$ & $\begin{array}{l}1.500 \\
35.6\end{array}$ & $\begin{array}{l}1.500 \\
35.1\end{array}$ & $\begin{array}{l}1.500 \\
74.4\end{array}$ & $\begin{array}{l}1.500 \\
42.7\end{array}$ \\
\hline$\alpha_{\text {Rice }}$ & $\begin{array}{l}0.780 \\
36.4\end{array}$ & $\begin{array}{l}0.727 \\
1.3\end{array}$ & $\begin{array}{l}0.892 \\
199.8\end{array}$ & $\begin{array}{l}0.752 \\
281.8\end{array}$ & $\begin{array}{l}0.712 \\
111.4\end{array}$ & $\begin{array}{l}0.839 \\
93.2\end{array}$ & $\begin{array}{l}0.890 \\
18.3\end{array}$ \\
\hline$\alpha_{\text {Wheat }}$ & $\begin{array}{l}1.171 \\
163.7\end{array}$ & $\begin{array}{l}0.881 \\
5.0\end{array}$ & $\begin{array}{l}1.099 \\
21.0\end{array}$ & $\begin{array}{l}1.374 \\
32.3\end{array}$ & $\begin{array}{l}5.425 \\
33.1\end{array}$ & $\begin{array}{l}1.035 \\
28.5\end{array}$ & $\begin{array}{l}1.024 \\
17.0\end{array}$ \\
\hline$\alpha_{\text {Maize }}$ & $\begin{array}{l}1.433 \\
38.4\end{array}$ & $\begin{array}{l}0.668 \\
11.1\end{array}$ & $\begin{array}{l}3.863 \\
14.5\end{array}$ & $\begin{array}{l}10.922 \\
23.5\end{array}$ & $\begin{array}{l}13.532 \\
23.0\end{array}$ & $\begin{array}{l}0.030^{\circ} \\
31.9\end{array}$ & $\begin{array}{l}0.030^{*} \\
16.5\end{array}$ \\
\hline$\alpha_{\text {sorghum }}$ & $\begin{array}{l}2.095 \\
43.7\end{array}$ & $\begin{array}{l}0.168 \\
5.0\end{array}$ & $\begin{array}{l}0.030^{*} \\
14.5\end{array}$ & $\begin{array}{l}0.030^{*} \\
17.3\end{array}$ & $\begin{array}{l}49.332 \\
20.5\end{array}$ & $\begin{array}{l}0.030^{2} \\
30.3\end{array}$ & $\begin{array}{l}0.793 \\
16.9\end{array}$ \\
\hline$\alpha_{\text {Millet }}$ & $\begin{array}{l}0.720 \\
48.7\end{array}$ & $\begin{array}{l}0.586 \\
9.4\end{array}$ & $\begin{array}{l}0.934 \\
16.0\end{array}$ & $\begin{array}{l}0.806 \\
17.7\end{array}$ & $\begin{array}{l}2.346 \\
39.6\end{array}$ & $\begin{array}{l}1.205 \\
68.5\end{array}$ & $\begin{array}{l}0.672 \\
19.7\end{array}$ \\
\hline$\alpha_{\text {Other starchy }}$ & $\begin{array}{l}0.944 \\
30.9\end{array}$ & $\begin{array}{l}3.588 \\
6.9\end{array}$ & $\begin{array}{l}0.714 \\
14.2\end{array}$ & $\begin{array}{l}2.592 \\
16.5\end{array}$ & $\begin{array}{l}0.030^{\circ} \\
18.8\end{array}$ & $\begin{array}{l}0.592 \\
33.3\end{array}$ & $\begin{array}{l}0.159 \\
17.6\end{array}$ \\
\hline$\alpha_{\text {Root crops }}$ & $\begin{array}{l}0.383 \\
30.2\end{array}$ & $\begin{array}{l}0.030^{*} \\
5.9\end{array}$ & $\begin{array}{l}0.534 \\
14.7\end{array}$ & $\begin{array}{l}0.724 \\
16.5\end{array}$ & $\begin{array}{l}0.030^{*} \\
19.9\end{array}$ & $\begin{array}{l}0.841 \\
33.1\end{array}$ & $\begin{array}{l}0.959 \\
16.2\end{array}$ \\
\hline$\alpha_{\text {Soybean }}$ & $\begin{array}{l}2.624 \\
33.7\end{array}$ & $\begin{array}{l}1.231 \\
3.9\end{array}$ & $\begin{array}{l}3.467 \\
15.3\end{array}$ & $\begin{array}{l}6.385 \\
17.8\end{array}$ & $\begin{array}{l}0.030^{\star} \\
20.1\end{array}$ & $\begin{array}{l}0.030^{\prime} \\
30.0\end{array}$ & $\begin{array}{l}0.030^{*} \\
16.9\end{array}$ \\
\hline$\alpha_{\text {Oilseed }}$ & $\begin{array}{l}1.324 \\
28.2\end{array}$ & $\begin{array}{l}0.503 \\
5.4\end{array}$ & $\begin{array}{l}3.300 \\
17.7\end{array}$ & $\begin{array}{l}4.417 \\
23.9\end{array}$ & $\begin{array}{l}7.972 \\
31.3\end{array}$ & $\begin{array}{l}2.361 \\
29.1\end{array}$ & $\begin{array}{l}0.526 \\
17.0\end{array}$ \\
\hline$\alpha_{\text {cotton }}$ & $\begin{array}{l}6.796 \\
46.8\end{array}$ & $\begin{array}{l}35.730 \\
5.5\end{array}$ & $\begin{array}{l}10.066 \\
17.6\end{array}$ & $\begin{array}{l}9.360 \\
22.0\end{array}$ & $\begin{array}{l}6.079 \\
22.7\end{array}$ & $\begin{array}{l}18.836 \\
33.3\end{array}$ & $\begin{array}{l}11.477 \\
22.0\end{array}$ \\
\hline$\alpha_{\text {Sugarcane }}$ & $\begin{array}{l}1.043 \\
35.9\end{array}$ & $\begin{array}{l}0.030^{*} \\
5.0\end{array}$ & $\begin{array}{l}0.536 \\
14.7\end{array}$ & $\begin{array}{l}0.342 \\
15.8\end{array}$ & $\begin{array}{l}0.201 \\
24.1\end{array}$ & $\begin{array}{l}0.212 \\
49.6\end{array}$ & $\begin{array}{l}0.563 \\
20.7\end{array}$ \\
\hline$\alpha_{\text {Fibre }}$ & $\begin{array}{l}4.802 \\
34.6\end{array}$ & $\begin{array}{l}0.030^{*} \\
5.0\end{array}$ & $\begin{array}{l}2.889 \\
13.7\end{array}$ & $\begin{array}{l}2.577 \\
15.3\end{array}$ & $\begin{array}{l}13.924 \\
21.8\end{array}$ & $\begin{array}{l}11.246 \\
24.2\end{array}$ & $\begin{array}{l}39.267 \\
16.3\end{array}$ \\
\hline$\alpha_{\text {Tobacco }}$ & $\begin{array}{l}3.203 \\
31.5\end{array}$ & $\begin{array}{l}8.088 \\
7.3\end{array}$ & $\begin{array}{l}0.030^{*} \\
14.3\end{array}$ & $\begin{array}{l}7.062 \\
32.8\end{array}$ & $\begin{array}{l}6.844 \\
23.4\end{array}$ & $\begin{array}{l}4.713 \\
45.5\end{array}$ & $\begin{array}{l}1.391 \\
18.3\end{array}$ \\
\hline$\alpha_{\text {Tea }}$ & $\begin{array}{l}31.912 \\
32.8\end{array}$ & n..a. & $\begin{array}{l}10.469 \\
17.7\end{array}$ & $\begin{array}{l}12.199 \\
17.0\end{array}$ & $\begin{array}{l}17.698 \\
24.6\end{array}$ & $\begin{array}{l}11.082 \\
31.7\end{array}$ & $\begin{array}{l}0.030^{*} \\
17.2\end{array}$ \\
\hline$\alpha_{\text {Frult }}$ & $\begin{array}{l}1.674 \\
30.1\end{array}$ & $\begin{array}{l}1.241 \\
7.3\end{array}$ & $\begin{array}{l}1.427 \\
15.3\end{array}$ & $\begin{array}{l}2.504 \\
24.1\end{array}$ & $\begin{array}{l}1.901 \\
21.5\end{array}$ & $\begin{array}{l}2.206 \\
28.9\end{array}$ & $\begin{array}{l}1.885 \\
15.3\end{array}$ \\
\hline$\alpha_{\text {vegetables }}$ & $\begin{array}{l}0.346 \\
42.1\end{array}$ & $\begin{array}{l}0.267 \\
7.9\end{array}$ & $\begin{array}{l}0.364 \\
26.9\end{array}$ & $\begin{array}{l}0.484 \\
29.9\end{array}$ & $\begin{array}{l}0.347 \\
18.9\end{array}$ & $\begin{array}{l}0.461 \\
64.2\end{array}$ & $\begin{array}{l}0.335 \\
19.4\end{array}$ \\
\hline$\mu_{\text {Mix } 1}$ & $\begin{array}{l}-0.182 \\
41.6\end{array}$ & $\begin{array}{l}-0.182 \\
7.7\end{array}$ & $\begin{array}{l}-0.076 \\
12.5\end{array}$ & $\begin{array}{l}-0.014 \\
14.1\end{array}$ & $\begin{array}{l}0.121 \\
20.8\end{array}$ & $\begin{array}{l}-0.215 \\
35.1\end{array}$ & $\begin{array}{l}-0.376 \\
34.4\end{array}$ \\
\hline$\mu_{\mathrm{Mix} 2}$ & $\begin{array}{l}-0.083 \\
41.8\end{array}$ & $\begin{array}{l}0.203 \\
10.9\end{array}$ & $\begin{array}{l}-0.119 \\
29.8\end{array}$ & $\begin{array}{l}-0.043 \\
20.8\end{array}$ & $\begin{array}{l}0.054 \\
24.0\end{array}$ & $\begin{array}{l}-0.031 \\
30.7\end{array}$ & $\begin{array}{l}-0.022 \\
16.6\end{array}$ \\
\hline$\mu_{\mathrm{Mix} 3}$ & $\begin{array}{l}-0.014 \\
32.3\end{array}$ & $\begin{array}{l}0.021 \\
5.0\end{array}$ & n..a. & $\ddot{n}$. . & $\ddot{n}$.a. & $\begin{array}{l}-0.034 \\
35.7\end{array}$ & $\begin{array}{l}-0.043 \\
21.3\end{array}$ \\
\hline$\mu_{\mathrm{Mix} 4}$ & n... & $\ddot{n} . a$. & n.a. & $\ddot{n}$.a. & $\ddot{n}$.a. & $\ddot{n} . a$. & $\begin{array}{l}0.019 \\
17.6\end{array}$ \\
\hline
\end{tabular}

Notes:" parameter at bound; ${ }^{1}$ preset value. 


\section{Figure $8.5 \quad$ Shadow price of rice (yuan $/ \mathrm{kg}$ )}

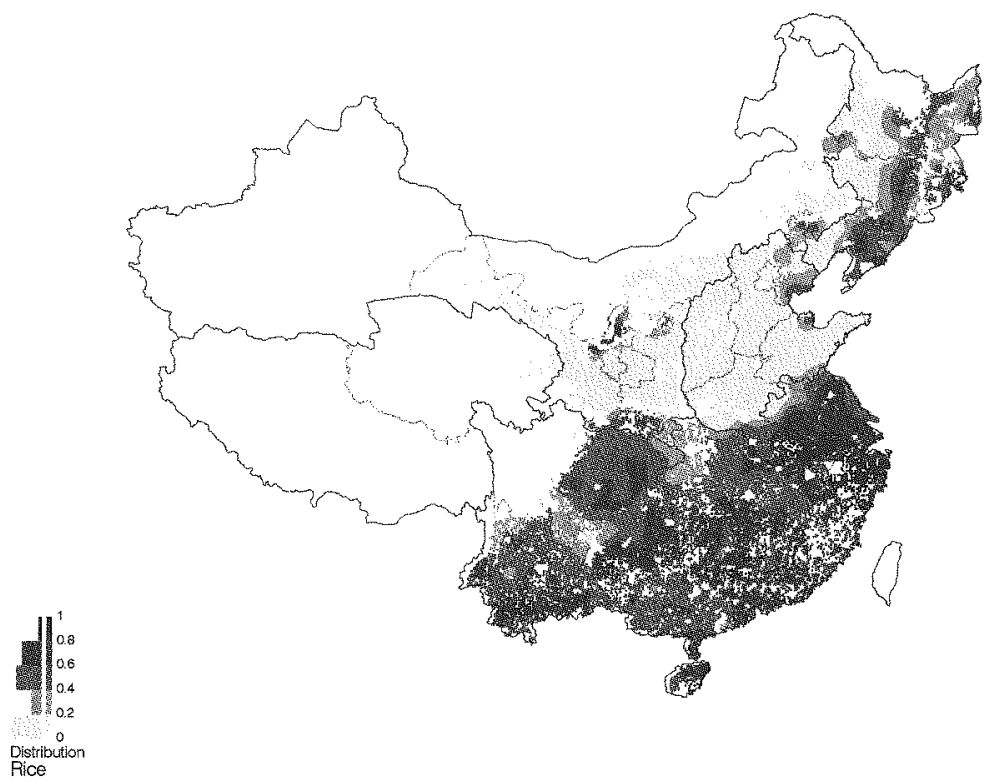

\section{Figure 8.6 Population density (persons $/ \mathrm{km}^{2}$ )}

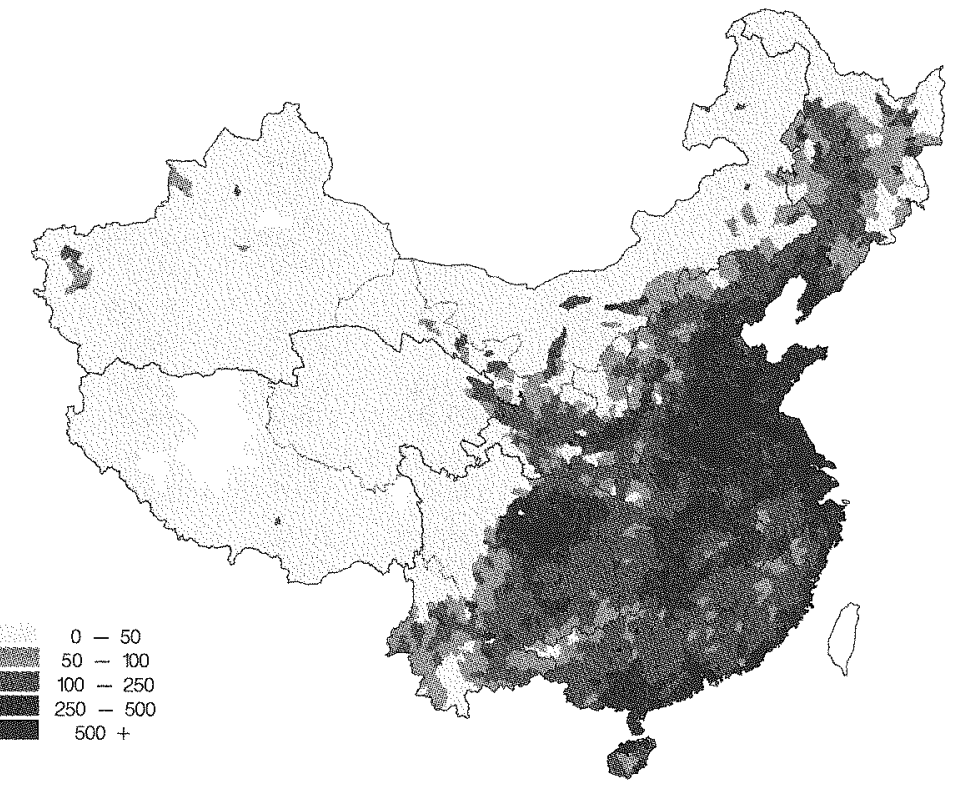


Towards estimating agricultural production relations for China

\section{Figure 8.7 Shadow price of wheat (yuan $/ \mathrm{kg}$ )}

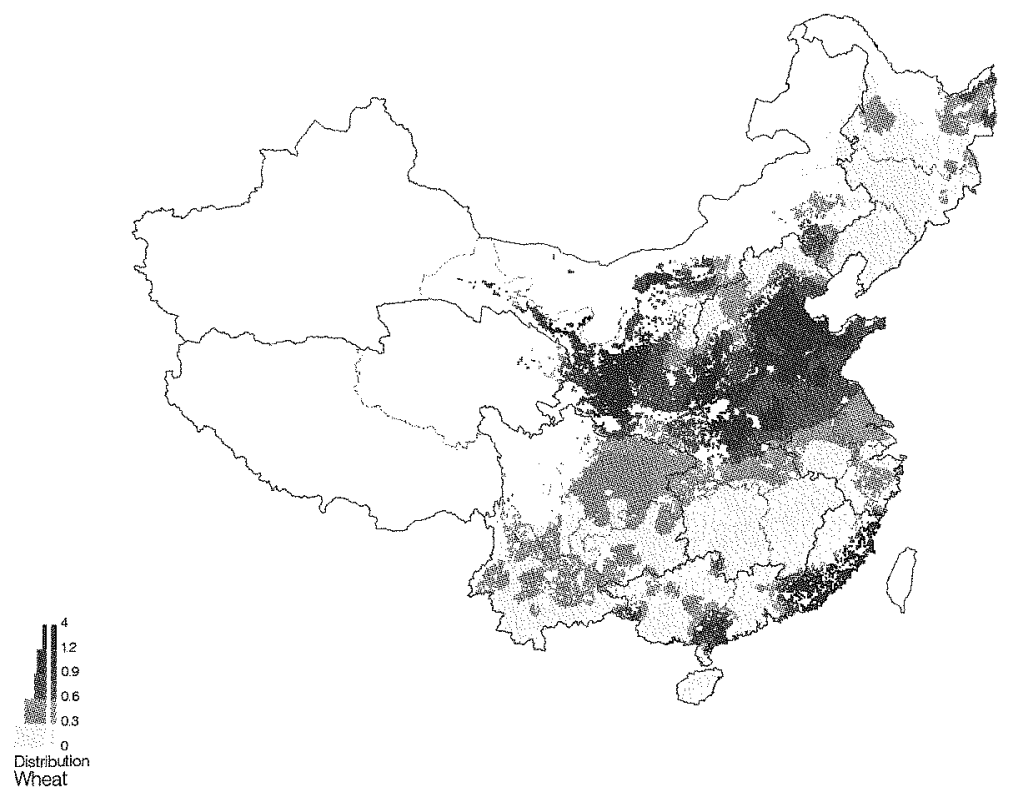

\section{Figure 8.8 Shadow price of maize (yuan $/ \mathrm{kg}$ )}
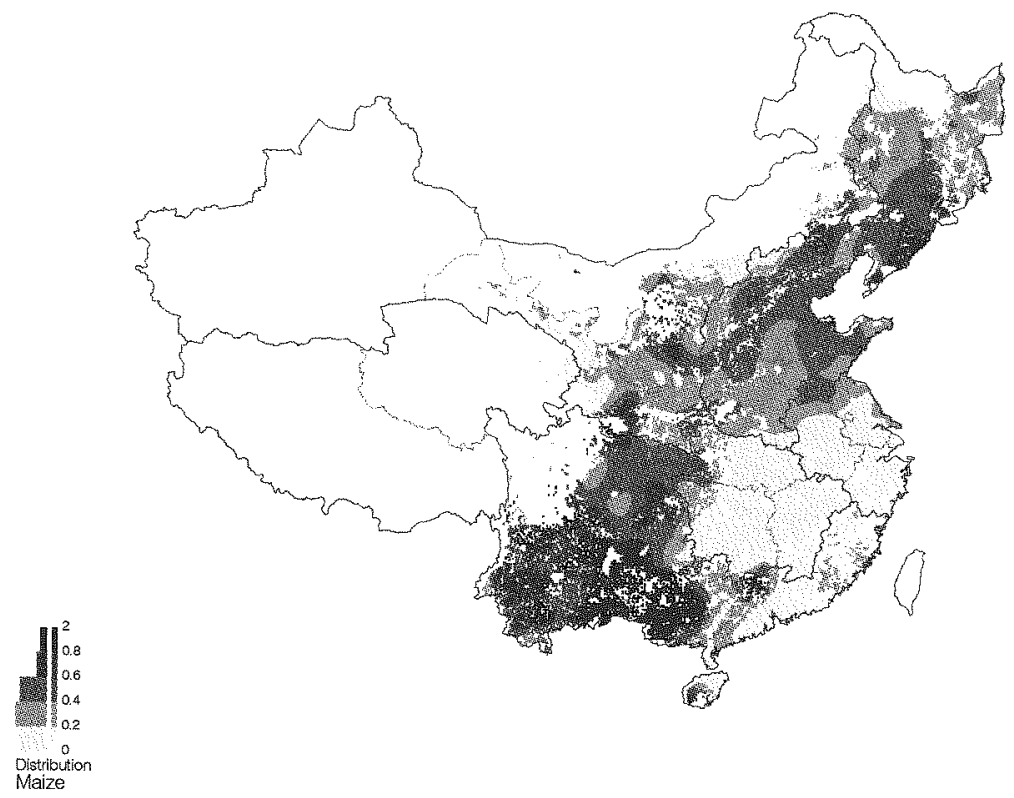
Dilemmas of China's Growth in the Twenty-First Century

Figure 8.9 Marginal productivity of labour (yuan/person)

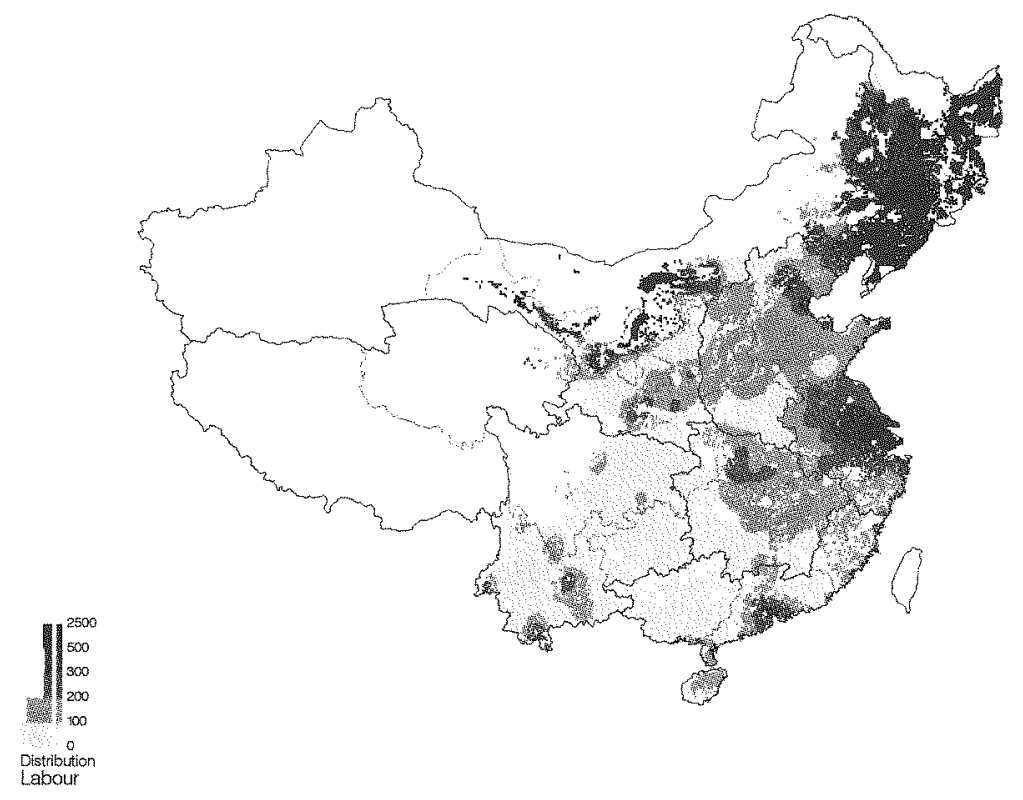

Figure 8.10 Marginal productivity of machinery (1000 yuan/10kW)

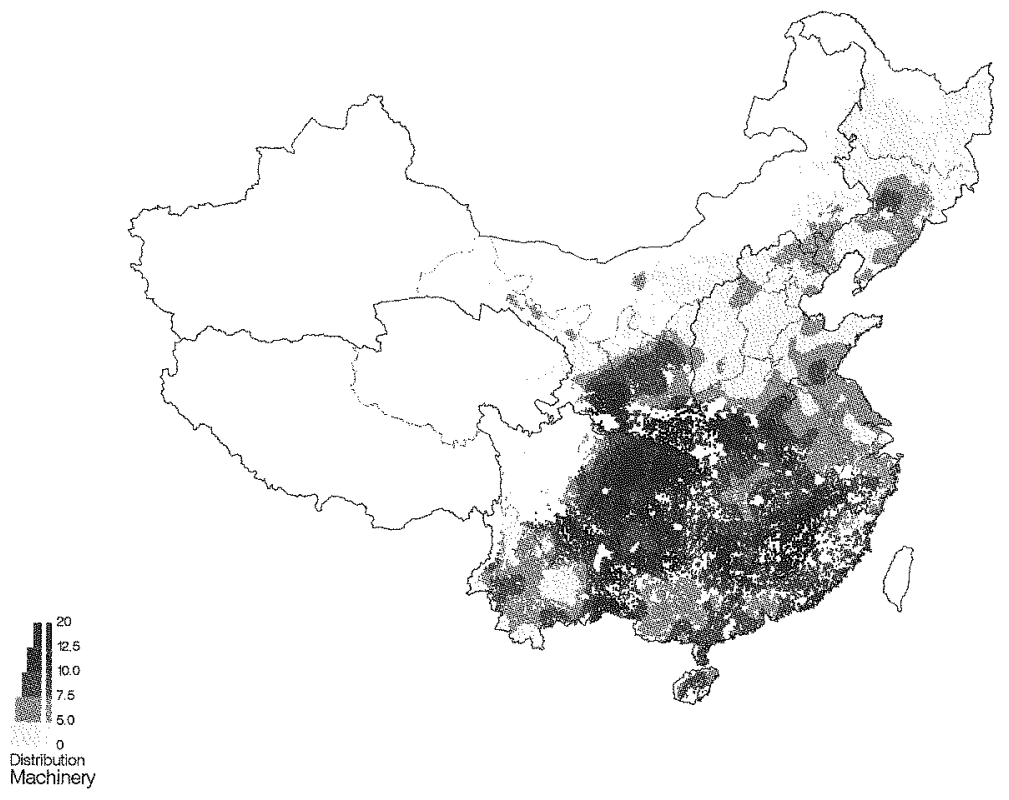




\section{Figure 8.11 Marginal productivity of irrigated land (yuan/ha)}

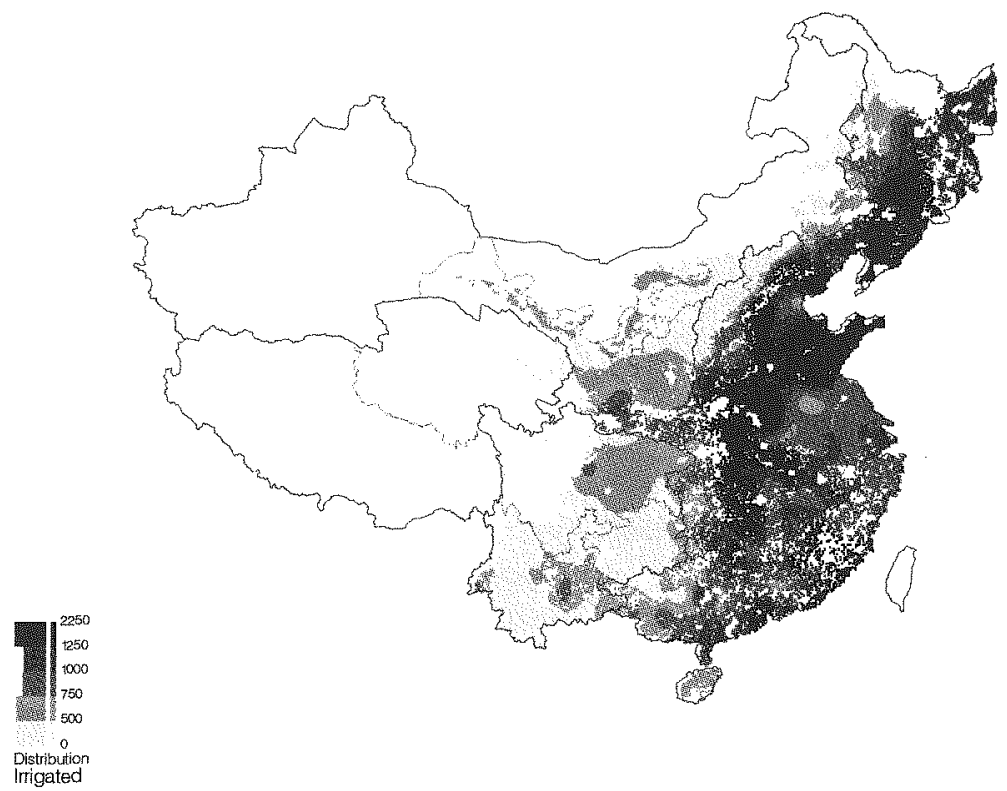

Table 8.11

Price comparison of original and shadow prices for the major crops

\begin{tabular}{|c|c|c|c|c|c|c|}
\hline Region & $\begin{array}{l}\text { Rice } \\
\text { Original }\end{array}$ & Shadow & $\begin{array}{l}\text { Wheat } \\
\text { Original }\end{array}$ & Shadow & $\begin{array}{l}\text { Maize } \\
\text { Original }\end{array}$ & Shadow \\
\hline $\begin{array}{l}\text { North } \\
\text { North East }\end{array}$ & 0.64 & 0.52 & 0.66 & 1.00 & $\begin{array}{l}0.53 \\
0.39\end{array}$ & $\begin{array}{l}0.42 \\
0.43\end{array}$ \\
\hline East & 0.65 & 0.75 & 0.57 & 0.68 & 0.56 & 0.41 \\
\hline Central & 0.60 & 0.59 & 0.58 & 0.73 & 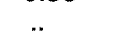 &.. \\
\hline South & 0.62 & 0.64 & & & & \\
\hline South West & 0.55 & 0.59 & 0.57 & 0.42 & 0.55 & 0.67 \\
\hline North West/Plateau & 0.71 & 0.61 & 0.64 & 0.84 & 0.46 & 0.39 \\
\hline
\end{tabular}

Note: Shadow prices using Equation 9.13 (regional average is weighted with production). Source: Original prices are from SSB, Survey Team of Urban Socio-Economy, $1992 \mathrm{~b}$. Yearbook of Price Statistics of China, 1992, China Statistical Publishing House, Beijing, (in Chinese). 


\section{Dilemmas of China's Growth in the Twenty-First Century}

Table 8.12 Input cost (yuan/labourer)

\begin{tabular}{lrrrrrrr}
\hline & North & $\begin{array}{l}\text { North } \\
\text { East }\end{array}$ & $\begin{array}{l}\text { Region } \\
\text { East }\end{array}$ & Central & South & $\begin{array}{l}\text { South } \\
\text { West }\end{array}$ & $\begin{array}{c}\text { North West/ } \\
\text { Plateau }\end{array}$ \\
Chemical fertiliser & 631 & 425 & 947 & 683 & 897 & 498 & 350 \\
Organic fertiliser & 176 & 16 & 301 & 213 & 456 & 249 & 66 \\
Machinery & 531 & 547 & 517 & 562 & 487 & 257 & 496 \\
Wage and land & 813 & 2321 & 673 & 580 & 631 & 287 & 666 \\
Total costs & 2151 & 3309 & 2438 & 2038 & 2471 & 1291 & 1578 \\
\hline
\end{tabular}

\section{Conclusion}

This chapter has reported on the specification and estimation of a spatially explicit transformation function for crop production in China, and indicates that the implicit prices associated with this function seem compatible with static profit maximisation at county level, at prices that correct for the distance from the main consuming areas. The next step is to conduct scenario simulations with such a profit-maximising model, after the inclusion of a livestock production and feed demand equation. We will then confront these with consumer demand and balance of payment restrictions. The final step will be to incorporate investment into irrigation and solve an intertemporal welfare model.

\section{Appendix 8.1}

\section{Description of the estimation procedure and calculation of partial derivatives for the Taylor expansion approach}

The transformation function described in the crop-mix output index of the input response function, can be written in more compact form as

$$
Q_{l}\left(Y, M ; \alpha_{0}, \alpha, \mu\right)=C_{l} G_{l}(V, A, \bar{y}(x) ; \theta, \rho, \beta, \gamma, \delta)
$$

where Greek symbols refer to parameters that should be estimated or fixed. On the output side $Q_{4}$ is a combination of a sum of crop-mix constants and a

$$
{ }^{\mathrm{CES}} Q_{\ell}=\left(1+\sum_{m} \mu_{m} M_{\ell m}\right)\left(\sum_{\mathrm{c}}\left(\alpha_{\mathrm{c}} \mathrm{Y}_{\ell \mathrm{c}}\right)^{\alpha_{0}}\right)^{1 / \alpha_{0}}
$$

and on the input side $\mathrm{C}_{l}$ is the sum of cropping zone constants

$$
C_{\ell}=\sum_{z} \zeta_{z} Z_{\ell z}
$$

while $G_{l}$ is the generalised Mitscherlich-Baule function

$$
\left.G_{\ell}=\prod_{j} f\left(\mathrm{~V}_{\ell}, \mathrm{A}_{\ell} ; \beta, \gamma ; \delta, \rho\right)\right)^{\theta_{j}} N\left(A_{\ell}, \overline{\mathrm{y}}_{\ell}(\mathrm{x}) ; \delta\right)
$$




\section{Towards estimating agricultural production relations for China}

with

$$
\begin{aligned}
& \mathrm{f}_{\ell \mathrm{j}}=1-\exp \left(-\beta_{\mathrm{j}}-\mathrm{w}\left(\mathrm{V}_{\ell} / \mathrm{H}_{\ell}\right)\right) \\
& \mathrm{w}_{\ell \mathrm{j}}=\left(\sum_{\mathrm{k} \in \mathrm{j}} \gamma_{\mathrm{k}}\left(\mathrm{V}_{\mathrm{k} \ell} / \mathrm{H}_{\ell}\right)^{\rho_{\mathrm{j}}}\right)^{1 / \rho_{\mathrm{j}}} \\
& \mathrm{H}_{\ell}=\sum_{\mathrm{s}} \delta_{\mathrm{s}} \mathrm{A}_{\ell \mathrm{s}} \quad \text { and } \\
& \mathrm{N}_{\ell}=\mathrm{H}_{\ell} \overline{\mathrm{y}}_{\ell}
\end{aligned}
$$

Index $l$ stands for counties, $m$ for crop-mix, $c$ for crops, $z$ for multiple cropping zones, $s$ for land-use types, $j$ for input groups and $k$ for inputs. Estimation is performed by each of seven regions.

\section{Numerical implementation of the estimation procedure}

As the estimation problem to be solved is highly nonlinear and non-convex in parameters, and relatively large and complex in parameters, it cannot be solved by invoking a standard numerical optimisation procedure. Therefore, it was necessary to develop an iterative procedure, which operates in five steps.

1. Generation of the initial quantities $\widetilde{q}_{\ell}=\widetilde{Q}_{\ell} / \mathrm{H}_{\ell}$ as data for the separate estimation of the input and the output function. Calculation of $\bar{y}_{\ell}=\bar{Y}_{\ell} / H_{\ell}$.

2. Iterative estimation of parameters of the input function $\tilde{q}_{\ell}=C_{\ell} \cdot G_{\ell} / H_{\ell}+\varepsilon_{1}$ by linear regression using a first-order Taylor expansion of the function, which is adjusted until convergence. This provides good initial estimates for Step 3.

3. Further estimation of the parameters of the input function in the original nonlinear form.

4. Estimation of parameters of the output function $\tilde{q}_{\ell}=Q_{\ell} / H_{\ell}+\varepsilon_{2}$ in the nonlinear form, for fixed substitution parameter $\alpha_{0}$.

5. Update the quantity index $\widetilde{q}_{\ell}$ and go to Step 3 until convergence.

Thus, Steps 1 and 2 constitute the initialisation and Steps 3 to 5 , the actual estimation. We note that a free nonlinear regression would do without separate data for the quantity index. Attempts to relax this restriction causes convergence problems in the estimation. It should be added that since the estimation problem is non-convex, only a stationary point could be obtained which appears to be a local optimum. The robustness of this estimate was tested by checking convergence to the optimal value after shocks and also by 


\section{Dilemmas of China's Growth in the Twenty-First Century}

assessing the resulting change in the other parameters in the calculation of the likelihood ratios (which performs new rounds of least squares, while iteratively setting parameters at half their originally estimated value). We conclude with some additional remarks on the various steps.

Step 1: The initial county-level output index $\tilde{Q}_{\ell}$ is calculated based on the available provincial prices $P_{r c}$, the national prices $P_{c}$ and the county-level crop outputs. The provincial crop output $Y_{\mathrm{rc}}$ is the sum of the county level outputs $Y_{l c}$. A provincial output price index $\mathrm{P}_{\mathrm{r}}^{\mathrm{i}}$ is calculated as

$$
P_{r}^{i}=\frac{\sum_{c} P_{r c} Y_{r c}}{\sum_{c} P_{c} Y_{r c}}
$$

to measure the departure of the provincial price level from the national price level. This provincial level price index, together with provincial level output prices, is applied to all counties $l$ in province $r$, yielding a country-level output index $\tilde{Q}_{\ell}$.

$$
\tilde{Q}_{\ell}=\sum_{c} Y_{\ell c} P_{\ell c} / P_{\ell}^{i}
$$

Step 2. The Taylor expansion uses two matrices e and $e_{p}$ of dimension $z \times \psi$. Let subscript $\mathrm{p}$ denote the results of the previous iteration. Using the definitions of Equations A8.1 and A8.2, the sum of squared disturbances $\mathrm{e}_{l}(\mathrm{z} ; \psi)$ can be written as

$$
e_{\ell}(\mathrm{z} ; \psi)=Q_{\ell}-C_{\ell}\left(\mathrm{Z}_{\ell z} ; \zeta_{\mathrm{z}}\right) \mathrm{G}\left(V_{\ell j}, \mathrm{~A}_{\ell s}, \bar{y}_{l s} ; \theta_{j}, \beta_{j}, \rho_{j}, \gamma_{k}\right) / \mathrm{H}_{\ell} \text { (A8.3) }
$$

and the derivatives are

a) partial derivative with respect to $\zeta_{z}$

$$
\frac{\partial e_{\ell}}{\partial \zeta_{z}}=-Z_{\ell z} G_{\ell} / H_{\ell}
$$

b) partial derivative with respect to $\theta_{j}$

$$
\frac{\partial e_{\ell}}{\partial \theta_{j}}=-\log f_{\ell j} C_{\ell} \mathrm{G}_{\ell} / \mathrm{H}_{\ell}
$$

c) partial derivative with respect to $\beta_{j}$

$$
\begin{aligned}
& \frac{\partial e_{\ell}}{\partial \beta_{j}}=-\theta_{j} \frac{1-f_{\ell j}}{f_{\ell j}} C_{\ell} G_{\ell} / H_{\ell} \\
& \text { d) partial derivative with respect to } \rho_{j}
\end{aligned}
$$

$$
\frac{\partial e_{\ell}}{\partial \rho_{j}}=\frac{-\theta_{j} w_{\ell j}}{\rho_{j}} \frac{1-f_{\ell j}}{f_{\ell j}}\left(\frac{\log w_{\ell j}^{\rho_{j}}}{\rho_{j}}-\frac{\sum_{k \in j}\left(\gamma_{k} v_{\ell k}^{\rho_{j}} \log v_{\ell k}\right)}{w_{\ell j}^{\rho_{j}}}\right) C_{\ell} G_{\ell} / H_{\ell}
$$

with $v_{\ell k}=V_{\ell k} / H_{\ell}$

e) partial derivative with respect to $\gamma_{k}, k \in j$ 


$$
\frac{\partial e_{\ell}}{\partial \gamma_{j}}=-\theta_{j} \frac{1-f_{\ell j}}{f_{\ell j}} \frac{1}{\rho_{j}} w_{\ell j}{ }^{1-\rho_{j}} v_{\ell j}{ }^{\rho_{i}} C_{\ell} G_{\ell} / H_{\ell}
$$

Step 3. To avoid parameters drifting away in the course of the estimation, the parameters $\zeta, \theta, \rho$ and $\eta$ are estimated keeping the others fixed, and next the parameters $\beta$ and $\gamma$ are estimated keeping $\zeta, \theta, \rho$ and $\eta$ fixed. The parameters are updated until convergence is reached. The update procedure of the parameters and convergence level are the same as in Step 2.

Step 4 . The parameter $\alpha_{0}$ is estimated by scanning over the interval $[1.5,2]$.

Step 5. Convergence is reached when two full rounds lead to less than 0.1 per cent change of the sum of squares of $\left(\hat{\tilde{Q}}_{\ell} / H_{\ell}-\hat{\mathrm{C}}_{\ell} \hat{G}_{\ell} / H_{\ell}\right)$

The entire estimation procedure was implemented in GAMS (Brooke et al. 1992). The databases for estimation of the output and input response functions were stored and managed as MS-Excel worksheets. The statistical software package SAS was used to transfer the basic data into GAMS format, with a proper declaration and initialisation of sets in GAMS syntax. The resulting database in GAMS format was stored with the save option 's = ..Idata', so that it can be used by the different parts of the GAMS programs independently using the restart option ' $r=$..ldata'.

\section{Appendix 8.2}

\section{Output elasticities of input $k$ and land input $s$ and of crop $c$}

Output elasticity with respect to input $V_{\ell k}$

$\frac{\partial G_{\ell}}{\partial V_{\ell k}} \frac{V_{\ell k}}{G_{\ell}}=\frac{1-f_{\ell j}}{f_{\ell j}} \theta_{j} \gamma_{k} w_{\ell j}^{1-\rho_{j}}\left(\frac{V_{\ell k}}{H_{\ell}}\right)^{\rho_{j}}$

Output elasticity with respect to land input of type $A_{\ell s}$ $\frac{\partial G_{\ell}}{\partial A_{\ell s}} \frac{A_{\ell s}}{G_{\ell}}=\frac{\delta_{s} A_{\ell s}}{H_{\ell}}\left(1-\sum_{j}\left(\theta_{j} \frac{1-f_{\ell j}}{f_{\ell j}} w_{\ell j}\right)\right)$

Output elasticity with respect to crop $Y_{l c}$

$$
\frac{\partial Q_{\ell}}{\partial Y_{\ell c}} \frac{Y_{\ell c}}{Q_{\ell}}=\frac{\left(\alpha_{c} Y_{\ell c}\right)^{\alpha_{0}}}{\sum_{c}\left(\alpha_{c} Y_{\ell c}\right)^{\alpha_{0}}}
$$

\section{Notes}

1 In this chapter the results emerging in the first stage of the estimation are presented. The full results and an extended analysis will be published soon in IIASA's peer-reviewed 


\section{Dilemmas of China's Growth in the Twenty-First Century}

Research Report Series, under the title 'Estimation of Agricultural Production Relations in the LUC Model for China'. The research of the LUC project is a multidisciplinary and collaborative effort. It has involved researchers at IIASA and in various collaborating institutions in China, Europe, Japan, Russia and the United States. For the work presented in this paper, the authors are grateful to the researchers who have developed and significantly contributed to the various themes: Silvia Prieler and Harrij T. van Velthuizen (IIASA, LUC) contributed to the AEZ modeling. Li Xiubin, Liu Yanhua, Zhao Mingcha (Institute of Geography, Chinese Academy of Sciences, Beijing) and Zheng Zenyuan (State Land Administration, Beijing) greatly supported the provision, adequate interpretation and compilation of data. Liu Jiyuan (Institute of Geographical Sciences and Natural Resources, Chinese Academy of Sciences, Beijing) kindly provided mapped data defining the spatial distribution of cultivated land.

2 All authors provided some specific contributions to the writing of this report. Günther Fischer and Laixiang Sun compiled the database. Günther Fischer developed the agroecological assessment model for China and estimated the biophysical potentials. Laixiang Sun and Peter Albersen estimated the input response function. Peter Albersen also estimated the output function, performed the final, joint estimation of the output and input components and computed the implicit prices. Michiel Keyzer provided general guidance and gave technical advice.

3 IIASA and SOW-VU cooperated in the construction of the LUC model.

4 The eight LUC economic regions are: north including Beijing, Tianjin, Hebei, Henan, Shandong and Shanxi; north-east including Liaoning, Jilin and Heilongjiang; east including Shanghai, Jiangsu, Zhejiang and Anhui; central including Jiangxi, Hubei and Hunan; south including Fujian, Guangdong, Guangxi and Hainan; south-west including Sichuan, Guizhou and Yunnan; north-west including Nei Mongol, Shaanxi, Gansu, Ningxia and Xinjiang; and plateau including Tibet and Qinghai.

5 For more information on various innovative models of land tenure see Dong (1996), Fahlbeck and Huang (1997), Wang (1993), Rural Sample Survey Office (1994), Chen and $\operatorname{Han}(1994)$ and Lin (1995).

6 There are two sets of farmland data in China. Most widely used is the data set published by State Statistical Bureau (SSB) in the Statistical Yearbook of China. Another data set was compiled by the State Land Administration (SLA), based on a land survey in the 1980s. SSB has noticed that its figures for cultivated areas may underestimate the actual extent. According to SSB, the area of cultivated and irrigated land in 1990 was only 95.7 and 47.4 million hectares, respectively, whereas the corresponding figures from SLA were 132.7 and 63.5 million hectares. Thus the irrigation share is similar on average but the differences between the estimates at province and national level are quite large (SSB 1994:329, 335; Fischer et al. 1998).

7 We note that econometric studies may underrate the role played by organic fertiliser because relevant statistical data are often lacking and where available they exhibit high correlation with total labour input.

8 This rate is calculated on the basis of the State Land Administration's (SLA) figure of the total farmland area, which was about 132 million hectares in 1995. SLA's farmland figure is based on a detailed land survey conducted from 1985-95, and is consistent with estimates derived from satellite imagery (see also Fischer et al. 1998). 


\section{Towards estimating agricultural production relations for China}

9 We used the total number of large animals as a proxy for draught animals. However, due to the poor performance of this proxy in all estimations, we finally had to drop it from the estimation.

10 Personal communications with Chinese officials suggest that the farmland data compiled by SLA based on detailed surveys will eventually replace the unrealistic estimates published in the Statistical Yearbook of China. Except where specifically mentioned, the data in this subsection are derived from various publications of China's State Statistical Bureau.

11 For detailed documentation and references regarding the compilation and editing of these land use and soil maps, see http://www.iiasa.ac.at/Research/LUC/

12 The alternative values against which the estimated values are tested, read: $\theta_{\text {Power }}=0.5$; $\zeta_{2}=1 ; \mathrm{m}_{\mathrm{rm}}=0 ; \rho_{\text {Power }}=-1.5 ; \rho_{\text {Nurrient }}=0.7$ or 1 ; and $\alpha_{0}=2$. For $\delta_{\text {Irrigared }}=1$, the ratio between the potential yield on irrigated land to the potential yield on rainfed land is used as the alternative and in the other cases if $\delta_{\text {Irrigated }}=1$ is the hypothesis, leading to the values $\delta_{\text {Irrigared }}=1.00,1.00,1.05,1.04,1.03,1.16$ and 1.00 , respectively, for the various regions. 